\title{
Neuropharmacology: Oxime antidotes for organophosphate pesticide and nerve agent poisoning
}

\author{
TAMARA ZORBAZ* \\ ZRINKA KOVARIK \\ Institute for Medical Research and Occupational \\ Health, Zagreb, Croatia \\ *Correspondance: \\ Tamara Zorbaz \\ E-mail: tzorbaz@imi.hr
}

Keywords: CNS drugs, 2-PAM, HI-6, RS194B, pharmacodynamics, ADME

\section{Abbreviations:}

ACh, acetylcholine

AChE, acetylcholinesterase

ADME, absorption, distribution, metabolism, and excretion

BBB, blood-brain barrier

BChE, butyrylcholinesterase

$\mathrm{BCRP}$, breast-cancer related protein

ChE, cholinesterase

CNS, central nervous system

CSF, cerebrospinal fluid; CYP, cythochrome P450 enzymes

HBA, hydrogen bond acceptors

$\mathrm{HBD}$, hydrogen bond donors

HSA, human serum albumin

IAM, immobilized artificial membrane

ISF, interstitial fluid

$\log \mathrm{P}$, partition coefficient (lipophilicity)

mAChR, muscarinic acetylcholine receptor

nAChR, nicotinic acetylcholine receptor

$\mathrm{NP}$, nanoparticles

NVU, neurovascular unit

$\mathrm{OP}$, organophosphorus compound

PAMPA, parallel artificial membrane permeability assay

PBPK, physiologically based pharmacokinetic

$P D$, pharmacodynamic

P-gp, P-glycoprotein

PK, pharmacokinetic

$\mathrm{RB}$, rotatable bonds

TPSA, total polar surface area

Received April 1, 2020

Revised June 3, 2020

Accepted June 8, 2020

\begin{abstract}
Organophosphate (OP) compounds remain a great threat for humans because they are used as pesticides or misused as chemical warfare nerve agents. Their mechanism of toxicity involves the irreversible inhibition of the acetylcholinesterase (AChE) enzyme important in the control of cholinergic neurotransmission at the periphery and in the brain. An available pharmacological treatment are oxime compounds, that are reactivators of $O P$-inhibited AChE. However, oximes are not equally effective for every possible OP and they cross the blood-brain barrier (BBB) poorly. Novel oximes are being designed and synthesized at a high rate and scale and their pharmacological efficiency is being addressed mostly with the in vitro reactivation assay. Nevertheless, only few newly synthesized oximes have shown comparable or better pharmacological properties than the ones developed more than 65 years ago beacuse oxime potential to act as efficient antidote in vivo depends on its pharmacokinetic and neuropharmacokinetics profile. This paper provides an overview of all the important aspects that should be accounted for in the search for a centrally active oxime. Furthermore, it lists the most important $B B B$ oxime delivery strategies employed until now, and the available pharmacokinetic data on old and new oximes.
\end{abstract}

\section{NEUROTOXIC ORGANOPHOSPHATES}

Teurological disorders include different conditions categorized as 1 neurodegenerative, neuroinflammatory, neuropsychiatric, and other diseases, and as such represent one of the major global public health challenges that affect hundreds of millions of peoples worldwide (1). Conditions that originate at the level of the central nervous system (CNS) are difficult to treat both pharmacologically and surgically due to the specific anatomy and physiology of the nervous system.

In addition, the nervous system is the target of many toxic compounds such as highly lethal synthetic organophosphorus compounds (OPs) derived from phosphorous, phosphonic, or phosphonic acid. They were primarily developed and used as pesticides; however, they turned out to be toxic for different species, including humans; therefore, many OP pesticides have been banned, e.g., parathion, dichlorvos $(2,3)$. The incidence of intentional/unintentional OP pesticide poisoning is about 3 million cases per year, while lethal outcomes of poisoning (about 200 000 cases) have mostly been recorded in developing or under-developed countries due to a lack of strict pesticide use regulation and proper medical care $(4,5)$. In addition, OPs are mostly colourless and odourless 


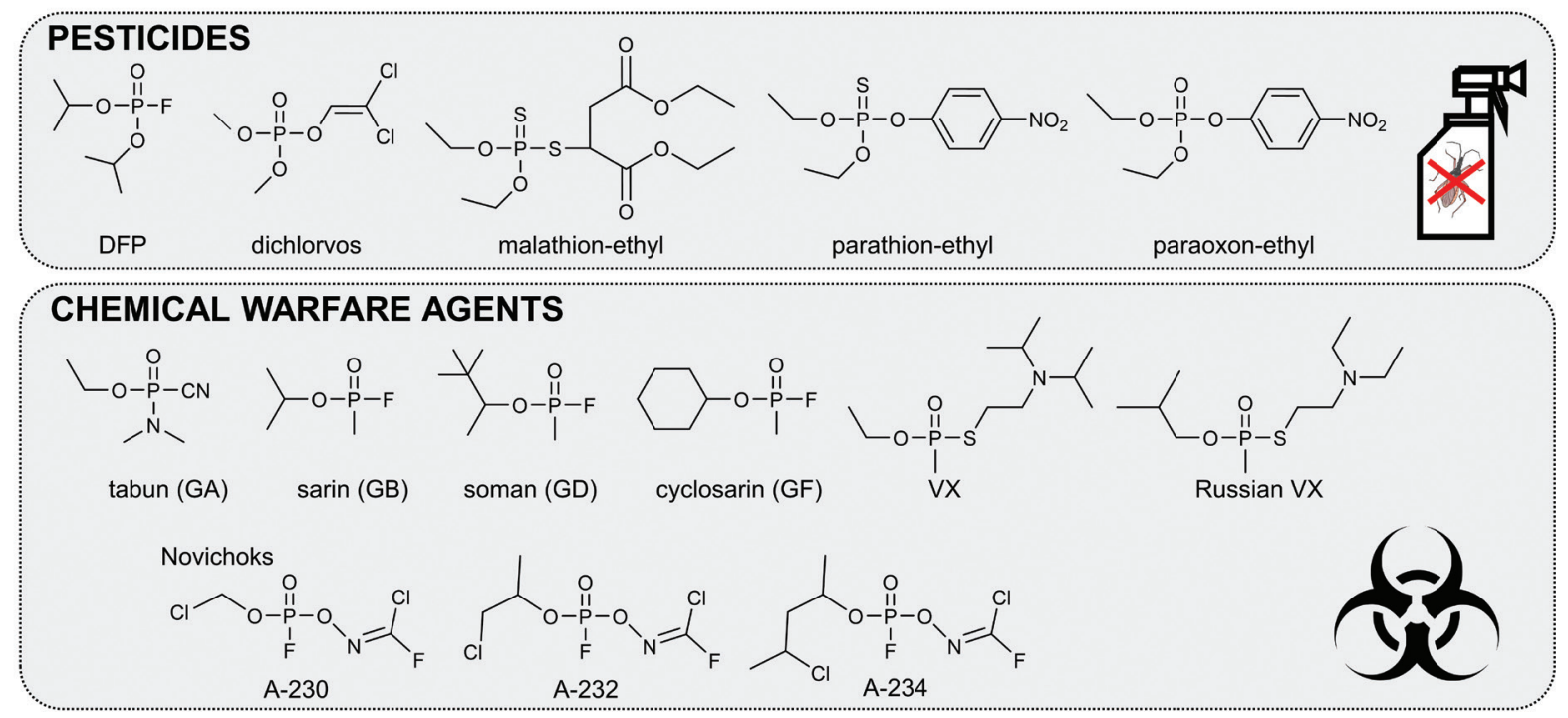

Figure 1. Chemical structures of organophosphorus pesticides and chemical warfare agents.

liquids, with high vapour pressure and lipophilicity that unfortunately makes them convenient and effective chemical weapons. Therefore, OPs have been used as nerve agents in terrorist or military attacks on several occasions despite the Chemical Weapon Convention enacted in 1997: sarin terrorist attacks in Matsumoto and the Tokyo (1994 and 1995) (6) and in Syria (2013) (7), or the VX assassination of Kim Jong-nam at the Malesian airport (2017) (8). Also, Novichocks, a less known class of OP chemical warfare agents developed in the Soviet Union (9), were allegedly used in the attempted assassination of Sergei and Yulia Skripal in Great Britain (2018) (10). The chemical structures of some OPs are depicted in Figure 1. Exposure to nerve agents is most likely to hap-

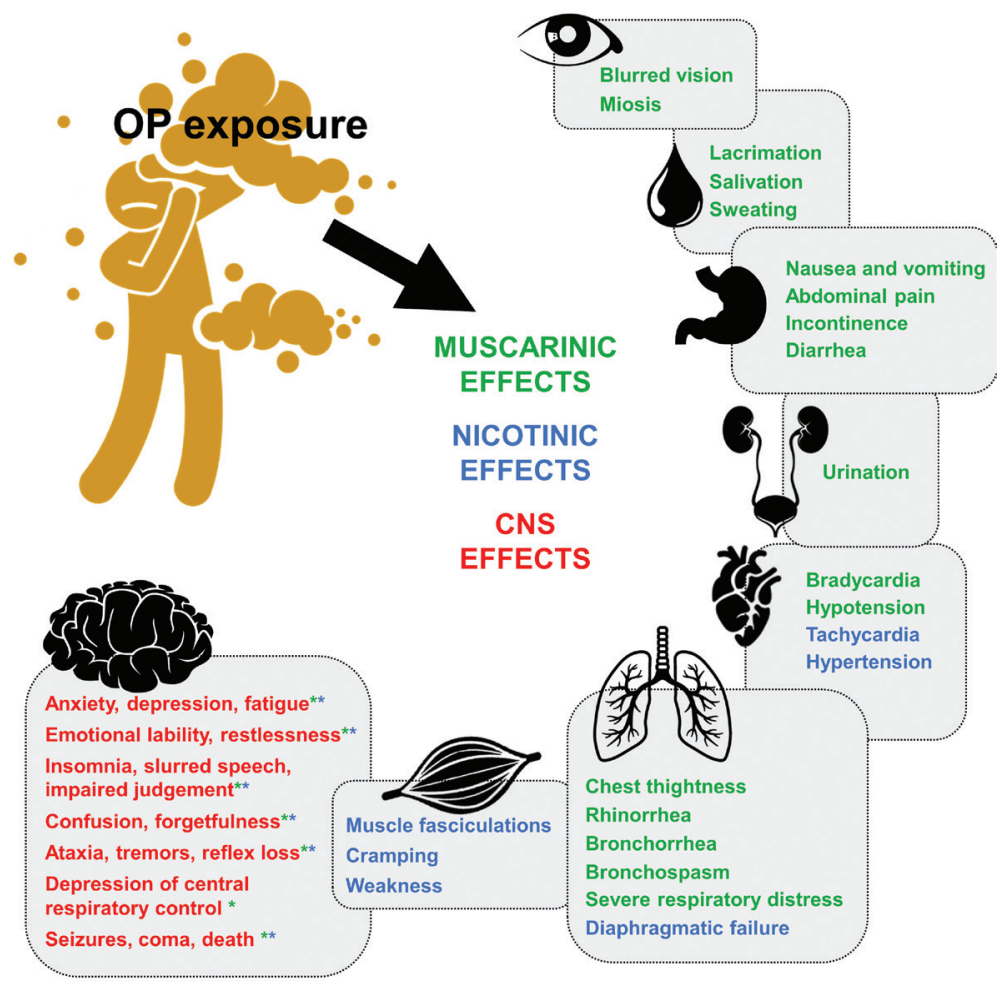

Figure 2. Symptoms of OP poisoning arising from overstimulation of muscarinic (green) and nicotinic (blue) receptors in the peripheral nervous system or in the CNS (red). 
pen by inhalation or through skin, but oral ingestion is also a possible and more probable route for intoxication with OP pesticides. Nevertheless, OPs exert a lethal effect at low doses by inhalation $\left(\mathrm{LC}_{50} \approx 5-150 \mathrm{mg} \mathrm{min} \mathrm{m}^{-3}\right)$ or by percutaneous exposure $\left(\mathrm{LD}_{50} \approx 20 \mathrm{mg} \mathrm{kg}^{-1}\right)$ (11).

The mechanism of acute toxicity of OPs is the irreversible inhibition of acetylcholinesterase (AChE; EC 3.1.1.7), an essential enzyme that regulates cholinergic signalling by catalysing the hydrolysis of the neurotransmitter acetylcholine (ACh). Butyrylcholinesterase (BChE; EC 3.1.1.8), which can serve as a backup enzyme for AChE along with other implied functions (12), is also inhibited by OPs. Both enzymes belong to a group of serine hydrolases termed cholinesterases (ChE). The spontaneous reactivation or de novo synthesis of the enzyme is far too slow $(-1-3 \%$ activity return per day) (13); therefore, due to the overstimulation of nicotinic and muscarinic acetylcholine receptors ( $\mathrm{AAChR}$ and $\mathrm{mAChR}$ ) by $\mathrm{ACh}$, an intoxicated organism experiences a cholinergic crisis. ACh takes part in the regulation of vital autonomic nervous system and brain functions, and therefore, $\mathrm{OP}$ poisoning can be recognized by miosis, excessive gland secretion, respiratory distress, tremor, and seizures among numerous symptoms listed in Figure 2.

If not treated rapidly, exposure to OPs is lethal due to respiratory failure and uncontrolled seizures (14). Moreover, studies have shown that survived animals that developed and sustained seizures after exposure to nerve agents developed brain damage and suffered from cognitive and behavioural impairments $(13,15-18)$. The proposed mechanism of the development of seizure activity and brain damage following OP exposure included cholinergic overstimulation that leads to disruptions of non-cholinergic systems, most importantly to the excitotoxic glutamatergic phase (19). Other secondary mechanisms implied to cause brain damage are oxidative stress, increased intracellular calcium, upregulation of inflammation factors and apoptosis in neuronal cells, with more details covered in the review by Kaur et al. (20). In addition, animal and cell line studies revealed that OPs change the expression of genes important for biological processes and canonical pathways that take part in degenerative and regenerative processes of the nervous system (21-24).

Prompt reaction and fast application of the treatment is crucial in counteracting the deleterious effects of AChE inhibition by OPs. Pharmacological intervention after OP poisoning includes symptomatic treatments comprising drugs with antimuscarinic (e.g., atropine) and anticonvulsive (benzodiazepines) action. However, nicotinic effects, such as paralysis of respiratory muscles at neuromuscular junction, remain untreated. The real antidotes in OP poisoning are oximes that act as nucleophilic reactivators of inhibited $\mathrm{AChE}$ and they restore enzyme activity. Therefore, oximes could mitigate both muscarinic and nicotinic effects. However, the oximes available in medical practice (2-PAM, HI-6, or obidoxime) have several flaws. Firstly, they are not equally effective for all OP compounds and this issue is hardly ever going to be solved due to the different steric and electronic characteristics of various OPs. Secondly, some OP-enzyme complexes (e.g., soman-AChE) undergo fast dealkylation of phosporyl moiety (i.e., aging) and cannot be reactivated afterwards. Thirdly, they do not exert an effect in the CNS since they have a quaternary nitrogen atom in their structures which makes them permanently charged and they cross the blood-brain barrier (BBB) poorly (25-28). Whether a molecule is going to provide satisfying therapeutic effect depends on how it interacts with the molecular target (pharmacodynamic aspect), but also on how it is processed by the body (pharmacokinetic aspect). Therefore, the search for molecules with better pharmacodynamics and pharmacokinetic characteristics is still an ongoing pursuit with focus on the CNS active reactivators.

\section{PHARMACOKINETIC AND PHARMACODYNAMIC VIEWPOINT}

Both pharmacokinetic (PK) and pharmacodynamic (PD) aspects are primarily governed by the molecular (physicochemical) properties of a drug. Generally, PK aspects involve the absorption, distribution, metabolism, and excretion (ADME) of a drug and a PK profile represents the time-dependent drug concentration in an individual body compartment. The route of drug administration also dictates the onset of drug action, and can be extravascular (per os, intramuscular, subcutaneous, etc.) or intravascular (intravenous). The central body compartment includes blood as the first medium for a drug to be absorbed in, followed by well perfused organs such as the heart, kidney, liver and lungs, while more lipophilic drugs also distribute to compartments such as muscle, brain, and fat. The hepatic metabolism affects mostly lipophilic drugs that are biotransformed into more hydrophilic metabolites, while hydrophilic drugs are readily eliminated by renal excretion (via urine). Metabolic enzymes are divided to phase I and phase II enzymes, and the main metabolic enzyme family of phase I biotransformation are cytochrome P450 enzymes (CYP) that catalyse NADPHdependent oxygenation of mostly lipophilic compounds (29). Furthermore, proteins in blood and tissue can bind drug molecules, affect their distribution, and reduce their transport to the target site. This is important since only an unbound, free form of a drug can interact with the target and is considered pharmacologically active. PD studies mechanism of action and effects initiated by a drug. The target molecule has a defined affinity for a drug, while a drug has both, specific affinity and intrinsic efficacy in provoking the response by interaction with the target; both factors determine the overall potency of a drug. The oxime reactivation potency in vitro is assessed by determination of kinetic parameters that describe the 
affinity of an inhibited enzyme for an oxime, the firstorder reactivation rate constant achieved with an oxime, and the overall reactivation rate $(30,31)$. Finally, the drugability of a compound is also influenced by its toxicity and potency for causing unwanted side effects, which can result from a non-specific interaction with non-target molecules or from drug-drug interactions. All these aspects that determine the overall pharmacological activity of a compound are highlighted in Figure 3. With regards to an ideal oxime antidote for OP poisoning, it should be present at sufficient concentrations for a sufficient period of time in both the peripheral (neuromuscular synapses) and central (cholinergic brain areas) compartment after intramuscular administration, which is a standard route of self/buddy-administered first aid autoinjector. Furthermore, the ideal oxime should have a broad therapeutic window or well defined effective and toxic concentrations.

\section{NEUROPHARMACOKINETIC VIEWPOINT}

The process of drug distribution to tissues follows and/ or occurs simultaneously with drug absorption, metabolism, and elimination. A centrally active drug should be distributed into the CNS represented by the brain and the spinal cord. The brain parenchyma comprises neurons and glial cells (Figure 4), where neurons process nerve signals transmitted as the action potentials along the neuronal membrane and causes the release of neurotransmitters from the vesicles of the presynaptic cell. Neurotransmitters then diffuse through the synaptic cleft and bind to specific receptors at the postsynaptic cell (e.g., neuron, muscle, or gland) that triggers a cell response by changes in the ion flow across the cell membrane or through secondary messengers.

The uncontrolled entry of different endogenous and exogenous molecules into the CNS is prevented by the $\mathrm{BBB}$ located at the place of contact between capillaries and brain tissue. Since the brain surroundings and its ventricles are filled with cerebrospinal fluid (CSF), there is also the blood-cerebrospinal fluid barrier; however, the $\mathrm{BBB}$ is more significant due to a much larger surface area and localization (32). The main BBB unit, called a neurovascular unit (Figure 4), is composed of the capillary endothelial cells, pericytes, and astrocytes (32). The paracellular transport of molecules across the BBB is decreased by the presence of intercellular protein networks called tight junctions (TJs) (33-35). Otherwise, most of the transport across the $\mathrm{BBB}$ is transcellular - i.e., passive diffusion, facilitated diffusion, active transport, or, to a lesser degree, transcytosis $(32,33)$.

The most significant way of drug's entry to the brain is passive diffusion and it is a route by which small non-

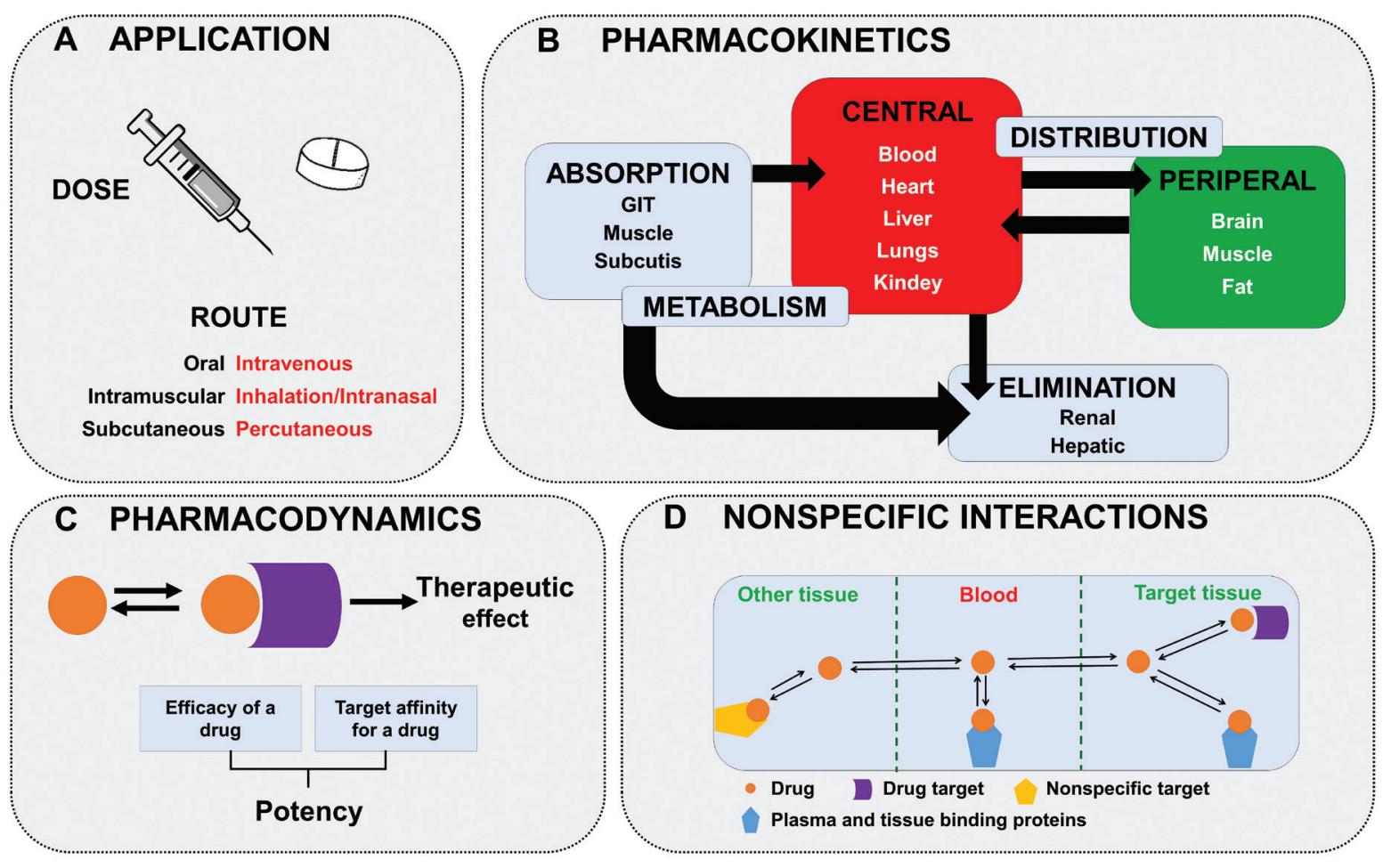

Figure 3. Relevant factors that define the therapeutic effect of a drug: A) dose and route of application, B) the pharmacokinetic profile of a drug, which includes its absorption, distribution, metabolism and elimination, $C$ ) a drug shows its potency at the target site through interaction with a target molecule (pharmacodynamics), D) a drug can interact with other molecules causing toxic effects or reducing the free and active form of the drug. 


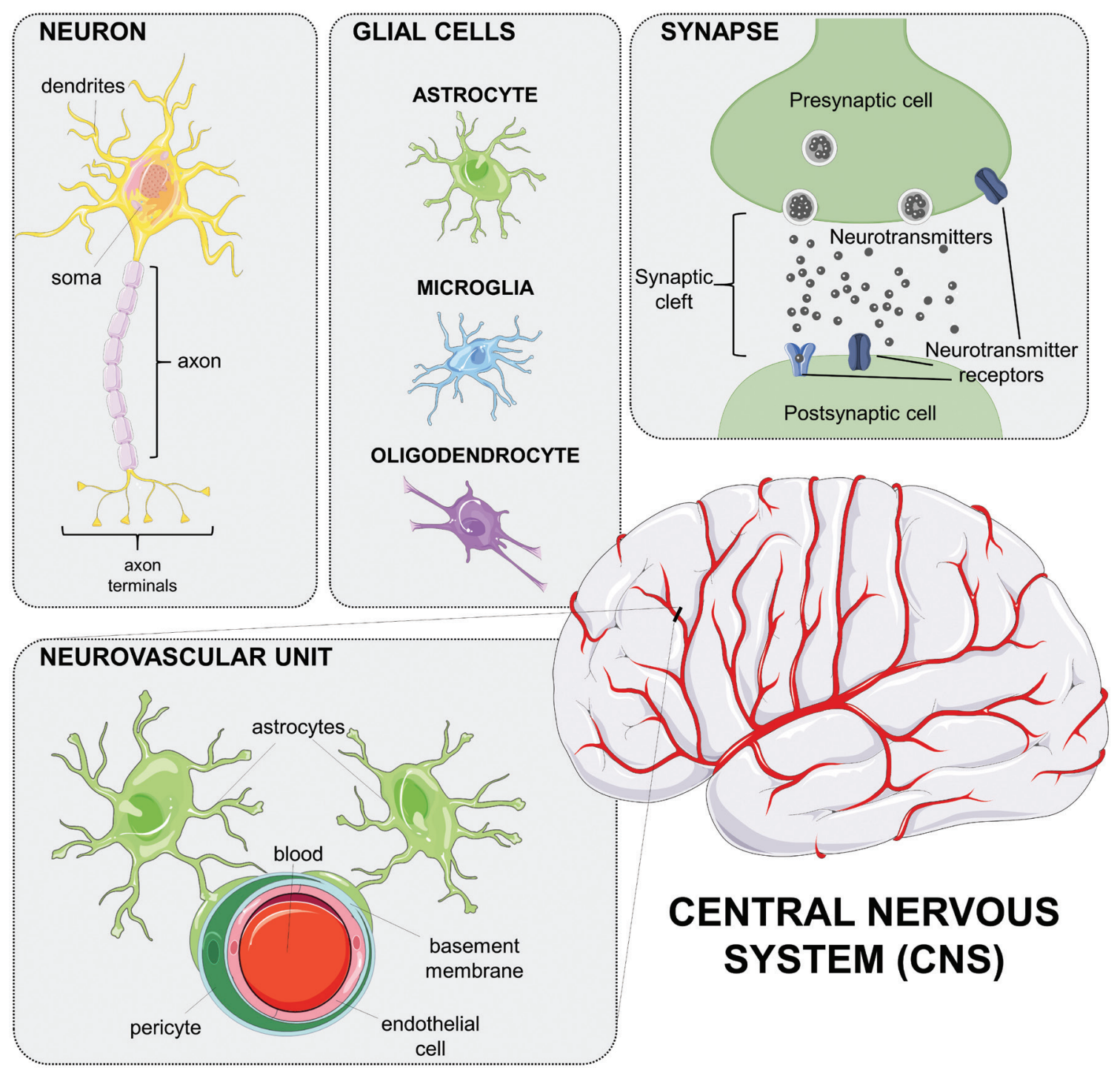

Figure 4. Main nervous system cell types - neuron and glial cells, synapse as the location of a neurotransmitter exchange between presynaptic and postsynaptic cell, and neurovascular unit of the blood-brain barrier.

polar molecules easily penetrate membranes. Moreover, membranes of endothelial cells of BBB have different types of transport proteins that primarily serve in supplying the brain with essential molecules such as glucose, amino acids, nucleosides, etc., and most of the transporters belong to the solute carrier transporter family (SLC) $(33,34)$. In addition, the BBB has transporters from the ATP-binding cassette (ABC) family that serve as efflux pumps and transport molecules back to the bloodstream. The most important efflux pumps, also known as multidrug resistance (MDR) proteins due to a decrease in drug concentrations at the target site, are P-glycoprotein (P-gp), breast-cancer related protein (BCRP), and several other MDR-related proteins $(32,33)$. The $\mathrm{BBB}$ also has the metabolic potential due to the presence of different intracellular enzymes that can biotransform a pharmacologi- cally active molecule into inactive or even toxic metabolites, or an inactive prodrug into an active form (34-36).

Therefore, the concentration of an active drug form available at the CNS target site depends on the plasma PK and plasma protein binding of the drug, but also on the neuropharmacokinetics of the drug that defines its distribution and change of concentrations within the brain. This is governed by the flow of extracellular fluid (CSF and interstitial fluid) between the brain tissue and ventricles, extracellular-intracellular exchange of molecules, and CSF turnover (37), while active concentrations of a drug can be reduced by the binding to brain tissue proteins. The neurotherapeutic effect also depends on the availability of a drug in different brain regions, where its molecular targets may be differentially expressed and may exert distinct functions (37). In conclusion, OP antidotes 
should achieve their effective concentrations of unbound form in the extracellular fluid of the brain. More precisely, the cholinergic system is the main target site for OP antidotes and recently the whole-brain cholinergic atlas of a mouse brain has been generated (38); it clearly shows the location of cholinergic neurons at the cortical and brainstem level, along with their projections to subregions of the forebrain and the midbrain. Moreover, the basal $\mathrm{ChE}$ activity in the brain of guinea pigs was ranked from the highest to the lowest following the order striatum > cerebellum $>$ brainstem $>$ spinal cord $>$ midbrain $>$ hippocampus $>$ cortex (39). These factors are all to be considered when evaluating an oxime's neuropharmacological effect.

\section{Prediction of BBB permeability and CNS activity}

The information on the neuropharmacokinetic profile of molecules in humans is highly limited and therefore, many in silico, in vitro, and in vivo animal studies combined with translational models are used instead. The majority of CNS drugs are small molecules that cross the $\mathrm{BBB}$ via the transcellular passive diffusion route (40). Lipinski's rule of five (Ro5) represents a pioneer set of recommendations for physicochemical properties for orally active drugs and for the rational drug design (41). Similarly, many research group defined threshold values for such parameters to help define CNS active candidates.

Firstly, the BBB penetration of molecules can be predicted by the analysis of their physicochemical parameters that describe size (molecular weight, MW), lipophilicity $(\log \mathrm{P}$ or $\log \mathrm{D})$, polarity (hydrogen bond donors and acceptors, HBD and HBA; total polar surface area, TPSA), flexibility (rotatable bonds, RB), and ionization of a molecule (charge dependent on $\mathrm{p} K_{\mathrm{a}}$ values of functional groups). Ideal CNS drugs are small ( $\mathrm{MW}<450)$, lipophilic $(\log \mathrm{P}<5)$, nonpolar molecules $(\mathrm{HBD}<3, \mathrm{HBA}<7$, TPSA $<60-70 \AA^{2}$ ) with a basic or amphiphilic character $\left(\mathrm{p} K_{\mathrm{a}}=7.5-10\right)$ and moderate flexibility $(\mathrm{RB}<8)(42)$.

Others developed central nervous system multiparameter optimization (CNS MPO); a desirability tool with flexible multiparameter approach rather than individual cutoffs for physicochemical properties $(43,44)$. This was designed to improve the quality of drug design and candidates nominated for clinical development with physicochemical properties complemental with the optimal ADME profile, $\mathrm{BBB}$ penetration, and low risk for adverse effects. A study by Rankovic (44) showed that lipophilicity and $\mathrm{p} K_{\mathrm{a}}$ were highly relevant properties to consider for minimizing the PK and toxicological drawbacks of compounds, e.g., compounds with lower-risk safety space had lower ClogP and higher TPSA, while MW, HBD, and TPSA were the most critical CNS-differentiating properties (45).
There are different in vitro methods to evaluate a drug's potential to be CNS active. The most common high throughput screening technique to determine the passive permeability potential of a molecule is the parallel artificial membrane permeability assay (PAMPA) which uses artificial "BBB like" membranes (46), especially porcine brain lipid extract-based PAMPA model (47). Alternatively, immobilized artificial membrane (IAM) chromatography can be used (48).

A range of in vitro cell cultures derived from a number of species are available for a two-compartment experimental configuration that model BBB for the determination of drug's permeability and have been described in a review by Helms et al. (49). Mono-culture configurations use either primary culture from isolated brain capillary endothelial cells or immortalized brain endothelial cell lines. Also, there are set-ups of co-cultures with astrocytes, or even triple-cultures with the addition of pericytes. Brain endothelial cells of bovine and porcine origin are well suited for the investigations of the transport of small molecules. Immortalized mouse or human brain endothelial cell lines, or even brain endothelial cells derived from human pluripotent stem cells (50) are commonly used and constantly improved to model BBB in permeability assays (49). In addition, a number of noncerebral immortalized cell lines are also used for drug permeability rate evaluations. The Madin-Darby canine kidney (MDCK) cell line is the most suitable (32), while the MDCK-MDR1 line with overexpressed P-gp was developed specially for the evaluation of the affinity of P-gp efflux pumps for tested molecules (51).

A number of in vivo and ex vivo methods for the assessment of $\mathrm{BBB}$ penetration of a drug are also available. Firstly, the most common approach to assessing BBB penetration is determining the brain and blood concentration following in vivo administration that yields the brain/ plasma ratio of a compound. However, this approach can be misleading if the compound is extensively bound to brain tissue or accumulates intracellularly or if the brain vasculature is not well perfused. An unbound compound brain concentration can be measured by using in vivo steady-state concentrations in brain interstitial fluid (ISF) or by in situ brain perfusion technique (32). Alternatively, the non-specific binding of a drug to brain tissue can be assessed by the brain slice uptake or brain homogenate binding method (52). An indirect method to estimate the unbound drug in brain ISF is measuring the concentration of a compound in the CSF; still, the CSF concentration is not necessarily the same as the ISF concentration due to different turnovers of two compartments. The only direct method to address the unbound compound concentration is an animal microdialysis study for the determination of time-dependent changes in unbound drug concentrations in the ISF or CSF of the brain $(32,53)$. 
Furthermore, the CNS activity of a compound in vivo can be defined through different PD biomarkers such as target occupancy, target site activation, physiological measures, disease process, and clinical endpoints (37). Target occupancy is a method for determining the proportion of the compound bound to the target molecule in the brain collected at PK profile-based optimal time using autoradiography or in the intact brain using PET and SPECT techniques $(32,37)$. In general, neuroimaging techniques (e.g., PET, SPECT, MRI, CT, and EEG) are useful tools for assessing anatomical, functional, biochemical or metabolic data after administration of potential centrally active drugs (37). For more detailed explanations, other reviews can be addressed $(32,37,54,55)$.
Finally, physiology-based pharmacokinetic (PBPK) modelling can be used as a mathematical multi-compartment modelling technique for predicting the PK and neuropharmacokinetic behaviour of a molecule in vivo and in humans based on physicochemical properties of drugs measured in vitro (56).

\section{CNS delivery strategies in OP poisoning}

There were more than several attempts to increase the BBB permeability of oxime reactivators by changing their structural characteristics or delivery methods (Figure 4). As the permanent charge of standard oximes is a property that hampers significant $\mathrm{BBB}$ penetration, this was the first issue to be addressed.
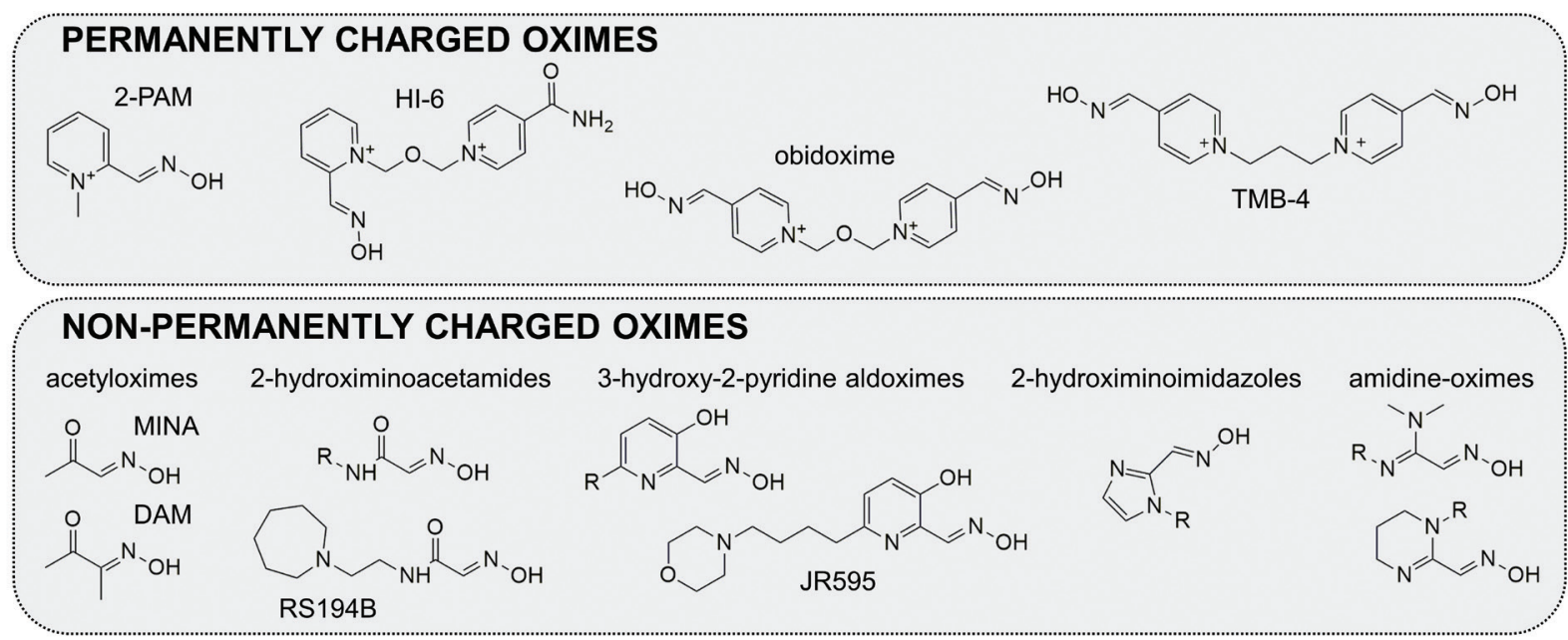

\section{CHARGED OXIMES WITH SUBSTITUENTS THAT INCREASE LIPOPHILICITY}

phenoxyalkyl pyridinium aldoximes

chloro-pyridinium aldoximes<smiles></smiles><smiles>O/N=C/c1cc[n+](COc2ccccc2)cc1</smiles>

fluoro-pyridinium aldoximes

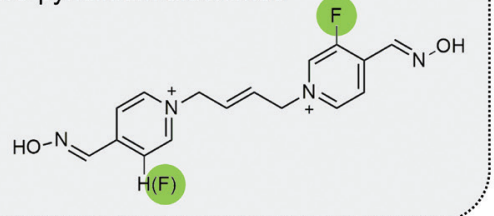

\section{ALTERNATIVE ATTEMPTS OF CNS OXIME DELIVERY}

\section{Pro-drug}

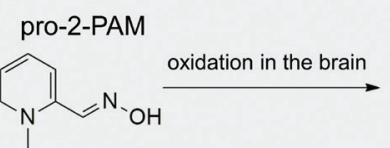

Glycosylated oximes

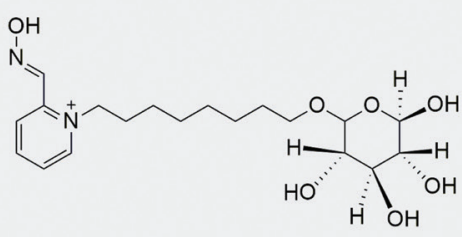

Nanoparticles with oximes
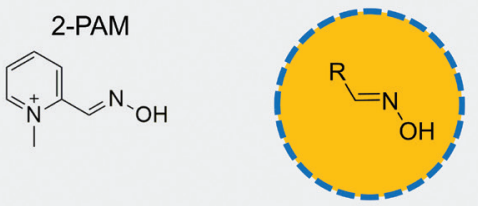

Oxime + P-gp inhibitor

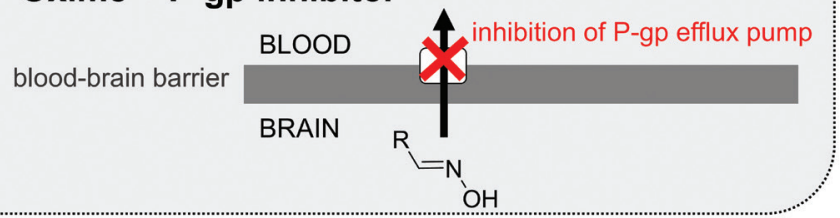

Figure 4. Oximes used in practice and different oxime scaffolds and strategies for CNS delivery. 
The first generation of non-permanently charged oximes with tertiary nitrogen atom were acetyloximes monoisonitrosoacetone (MINA) and diacetylmonoxime (DAM) (57). However, they were less potent peripheral reactivators than 2-PAM (58). About 10 years ago, the development of new tertiary oximes started. Different derivatives of 3-hydroxy-2-pyridinium oximes have been synthesised since and were proven to be potent reactivators of OP-inhibited $\mathrm{AChE}$ and $\mathrm{BChE} \mathrm{(59-64).} \mathrm{In} \mathrm{addition,} \mathrm{the} \mathrm{in} \mathrm{vivo} \mathrm{phar-}$ macological properties of few such oximes have also been evaluated (65-67). At the same time, the synthesis and activity of tertiary imidazole aldoximes and $N$-substituted 2-hydroxyiminoacetamides were also published (68-72) and the lead $N$-substituted 2-hydroxyiminoacetamide reactivator RS194B was studied quite extensively in different animal models (69, 73-76). Tertiary 3-fluoro-2-pyridinaldoximes were recently synthesised (77) providing a diverse molecular scaffold with fluorine that additionally influences lipophilicity. Furthermore, charged oximes were attached a substituent or moiety that increases the overall lipophilicity of the molecule and preferably governs its higher BBB penetration. Such are pyridinium oximes with phenoxyalkyl detergent-like substituents (78-80) or chlorine $(81,82)$ and fluorine atom $(83,84)$. There were other attempts to increase the oxime concentration in the brain. One of them was the synthesis of an uncharged pro-2PAM that oxidizes into 2-PAM in the brain (85). Furthermore, glycosylated oximes were synthesized to increase the brain uptake of an oxime by active glucose transporters at the BBB $(86,87)$. Incorporating oximes in the nanoparticles $(\mathrm{NP})$ that cross the $\mathrm{BBB}$ via transcytosis was used for the attempted improvement in brain delivery of standard oximes 2-PAM, HI-6 and obidoxime (88-91) or 3-hydroxy-2-pyridine oxime (67). NP can have various ligands (e.g., transferrin, folate, leptin, etc.) attached to their surface that would be recognized by specific receptors/transporters expressed by endothelial cells of the BBB, and therefore, would potentially result with improved brain targeting (92). The co-administration of an inhibitor of efflux transporter P-gp is also used for achieving higher oxime concentrations in the brain (93).

An additional possibility in treatment and CNS protection is the prophylactic intraveneous (i.v.) administration of BChE when exposure is likely. This way, the plasma $\mathrm{BChE}$ bioscavenging capacity increases, i.e., the capacity for irreversible binding of OP molecules which prevents them from reaching synapses and AChE (94). Exogenous administration of $\mathrm{BChE}$ showed protection against lethal doses of soman or VX (95) or sarin (96). The combination of an oxime that reactivates $\mathrm{BChE}$, or various AChE mutants, can offer a pseudo-catalytic scavenging of OPs - i.e., cycles of enzyme inhibition by OP coupled with oxime reactivation of the inhibited enzyme $(68,72,97-100)$. Advancements in this field were covered in the recent review by Kovarik and Maček Hrvat (101).
More strategies for general brain drug delivery were listed in previous reviews $(32,34,35)$. For example, hypertonic solution, compounds that modify TJs between brain capillary endothelial cells, and ultrasound or electromagnetic radiation were used to disturb the BBB integrity and increase its permeability (34). However, these approaches are quite non-selective and have numerous potential side effects. The intranasal (i.n.) route seems like another acceptable and promising brain delivery method for oximes. Drugs can be absorbed from the nasal cavity by olfactory mucosa $(5-10 \%$ of surface) directly to the brain via olfactory epithelium cells or nerves or they can be absorbed by the respiratory mucosa to systemic circulation and then distributed to the brain across the BBB (102). Qualitatively similar physicochemical property requirements are listed for drugs with good nasal bioavailability as the ones for BBB penetrating drugs (42-45), while permeation enhancers or other strategies could be applied to additionally improve the bioavailability (103). It is important to mention that the benefit of the i.n. route is the possibility of self-administration and non-invasiveness. Moreover, comparative studies have shown that the onset of action after i.n. application is comparable with the one after i.m. or s.c. injection (104).

\section{PHARMACOKINETIC DATA ON OXIMES}

\section{Absorption and circulation time}

After i.m. application, the oxime is absorbed into the blood and the maximal concentration $\left(C_{\max }\right)$ in the blood is achieved after the absorption process is completed and after a defined time $\left(t_{\max }\right)$. From there on, the elimination process takes place and exponential decrease of the oxime concentration in plasma is described by the elimination half-life $\left(t_{1 / 2}\right)$. The elimination is more than $90 \%$ complete after the time equal to four half-lives. Precise definitions and equations for PK parameters can be found elsewhere (105). Two-phase exponential decrease of oxime blood concentration can be observed in case of simultaneous distribution and elimination. The onset of an oxime's action depends primarily on the rate of its absorption and time needed to reach the target sites that are synapses of both the peripheral and central nervous systems. Naturally, the absorption process after i.m. application is governed by the properties of the oxime itself, but also highly depends on the model species. The published data on absorption and elimination of standard and charged oximes 2-PAM, HI-6, obidoxime, and TMB-4 after i.m. administration is summarized in Table 1.

In general, the absorption rate of all charged oximes after $i . m$. application is similar within the species. The maximal plasma concentration was achieved relatively fast in rodents (roughly 5-20 min) $(106,107,112-115,117)$ although some exceptions were observed in several studies for oxime HI-6 and TMB-4 ( $\left.t_{\max }>30 \mathrm{~min}\right)(114-116$, 121). In humans, the $t_{\max }$ for 2-PAM was slightly shorter (109-111) than for HI-6 and obidoxime (119, 120). 
Table 1. Absorption and elimination of i.m. applied standard oximes. Pharmacokinetic parameters: $t_{\max }$ - time needed to reach the maximal plasma concentration of an oxime $\left(C_{\max }\right), t_{1 / 2}$ - elimination half-life, time needed for plasma concentration $C_{\max }$ to be reduced in half, MRT - mean residency time, represents the average time of a molecule in the body.

\begin{tabular}{|c|c|c|}
\hline Oxime & Absorption, $t_{\max }$ & Elimination, $t_{1 / 2}$ \\
\hline 2-PAM & $\begin{array}{l}\text { Mouse: } 5 \min (65)^{*} \\
\text { Rat: } 5-20 \min (106,107) \\
\text { Sheep: } 12 \min (108) \\
\text { Human: } 5-23 \min (109-111)\end{array}$ & $\begin{array}{l}\text { Mouse: } \mathrm{MRT}=30 \mathrm{~min}(65)^{*} \\
\text { Rat: } 30-70 \mathrm{~min}(106,107) \\
\text { Sheep: } 29 \min (108) \\
\text { Human: } 75-100 \min (109-111,122)\end{array}$ \\
\hline HI-6 & $\begin{array}{l}\text { Mouse: } 7 \text { min }(65)^{*} \\
\text { Rat: } 5-45 \min (112-117) \\
\text { Dog: }<30 \min (117) \\
\text { Rhesus monkey: } 25-30 \min (117) \\
\text { Pig: } 10 \min (118) \\
\text { Sheep: } 14 \min (108) \\
\text { Human: } 30-60 \text { min (119) }\end{array}$ & $\begin{array}{l}\text { Mouse: } \mathrm{MRT}=45 \mathrm{~min}(65)^{*} \\
\text { Rat: } 20-65 \mathrm{~min}(112,113,116,117) \\
\text { Dog: } 40-50 \mathrm{~min}(117) \\
\text { Rhesus monkey: } 25-30 \mathrm{~min}(117) \\
\text { Pig: } 80 \text { min }(118) \\
\text { Sheep: } 52 \text { min }(108) \\
\text { Human: } 80-85 \min (119)\end{array}$ \\
\hline Obidoxime & $\begin{array}{l}\text { Rat: } 10 \min (114) \\
\text { Human: } 20-30 \min (120)\end{array}$ & Human: $80 \min (120,121)$ \\
\hline TMB-4 & Rat: $15-40 \min (106,115,121)$ & Rat: $30-110 \min (106,121)$ \\
\hline
\end{tabular}

Furthermore, one of the major pharmacokinetic drawbacks of charged oximes is their short circulation time and short duration of pharmacological action. As observed, charged oximes also exhibited a shorter circulation time in smaller mammals than in larger mammals, as expected due to a more rapid metabolism and elimination in the former (123). Standard oximes in humans have a similar $\mathrm{t}_{1 / 2}$ of 80-100 min, implying almost total elimination within 5-7 hours $(109,119,120,122)$. Thiermann et al. demonstrated a two-phase exponential decay of obidoxime with half-lives of $2 \mathrm{~h}$ and $14 \mathrm{~h}$ in case of a clinical therapy of human OP pesticide poisoning (124). For other charged oximes, PK analyses showed similar absorption rates, i.e., $\mathrm{K} 027$ and $\mathrm{K} 203$ achieved their $C_{\max }$ in $40-60 \mathrm{~min}$ in rats $(115,121,125,126)$ and in pigs after
20 min (127), as well as similar elimination. In rats, K027 showed a somewhat slower elimination with a $\mathrm{t}_{1 / 2}$ of 128 min (121). The elimination $t_{1 / 2}$ in pigs for K027 and K203 was comparable to that of HI-6, with values of $93 \mathrm{~min}$ and $100 \mathrm{~min}$, respectively (127). Oral application of standard oximes was also evaluated in human studies that showed that maximal blood concentration is achieve within 30-180 min for 2-PAM (128, 129), 60-120 min for obidoxime $(130,131)$, or 36-96 min for HI-6 (132), however, the oral bioavailability was very low for all oximes. For comparison, the bioavailability of HI- 6 after i.m. application was $100 \%$ (113).

As for uncharged oximes, several studies have analysed their PK behaviour and demonstrated the same flaws concerning their circulation time as for the charged oximes

Table 2. Absorption and elimination of i.m. applied non-permanently charged oximes. Pharmacokinetic parameters: $t_{\text {max }}-$ time needed to reach the maximal plasma concentration of an oxime $\left(C_{\max }\right), t_{1 / 2}$ - elimination half-life, time needed for plasma concentration $C_{\max }$ to be reduced in half, $M R T$ - mean residency time, represents the average time of a molecule in the body.

\begin{tabular}{|c|c|c|}
\hline Oxime & Absorption, $t_{\max }$ & Elimination, $t_{1 / 2}$ \\
\hline RS194B & $\begin{array}{l}\text { Mouse: } 5 \min (69,76) \\
\text { Guinea pig: } 30 \min (75) \\
\text { Macaque: } 60 \min (74)\end{array}$ & $\begin{array}{l}\text { Mouse: } 12 \min (69) \\
\text { Guinea pig: } 52 \min (75) \\
\text { Macaque: } \text { n.s. }(74)^{*}\end{array}$ \\
\hline RS41A & Mouse: $5 \min (69,76)$ & Mouse: $11 \min (69)$ \\
\hline JR595 & Mouse: $15 \min (66)$ & Mouse: $14 \mathrm{~min}, \mathrm{MRT}=25 \min (66)$ \\
\hline GM415** & - & Rat: $18 \min (67)$ \\
\hline GM508*** & Mouse: $14 \min (65)$ & Mouse: $\mathrm{MRT}=40 \mathrm{~min}(65)$ \\
\hline GM113*** & Mouse: $17 \min (65)$ & Mouse: $\mathrm{MRT}=49 \min (65)$ \\
\hline \multicolumn{3}{|c|}{$\begin{array}{l}{ }^{*} \text { More than } 90 \% \text { of } C_{\text {max }} \text { was eliminated from plasma } 8 \mathrm{hr} \text { after application. n.s.- measured but not stated. } \\
{ }^{* *} \text { GM415 in rats was i.v. applied (67). } \\
{ }^{* * *} \text { GM508 and GM113 in mouse were i.p. applied (65). }\end{array}$} \\
\hline
\end{tabular}


(Table 2). $\mathrm{N}$-substituted 2-hydroxyiminoacetamide oximes RS194B and RS41A showed fast absorption within 5 minutes in mice (69, 76), while PK studies on RS194B showed slower absorption and slightly longer circulation times in guinea pigs (75) and macaques (74). Worth mentioning is that RS194B demonstrated an abundant absorption after $i . m$. application ( $88 \%$ bioavailability). Sustained plasma concentrations of RS194B in mice were provided by repeated oral administration following the initial i.m. dose (76). Similarly, 3-hydroxy-2-pyridine oximes (JR595, GM415, GM508, GM113) demonstrated fast absorption and rapid elimination in mice and rats (65-67). Oximes 2-PAM and GM415 encapsulated in NP showed significant prolongation of the their circulation time relatively to the free oxime $(67,91)$.

\section{Metabolism and route of elimination}

For charged oximes 2-PAM, HI-6, obidoxime, and TMB-4, it was demonstrated in several animal species that the main elimination route is renal $(106,112,117$, $119,120,122,133,134)$. The high renal clearance of 2-PAM in human suggested its active renal elimination via renal tubulae $(122,135)$. In addition, studies in human showed that $80-90 \%$ of applied dose was eliminated unchanged in urine within 24 hours $(110,122)$. Studies in dogs and rats showed that $60 \%$ of HI- 6 was eliminated unchanged in the urine, and $40 \%$ was presumably metabolized and excreted in urine since there was no HI-6 in bile or feces $(117,133,134)$. However, the total metabolism of HI-6 was of low significance for its biological activity (112). In man, the renal elimination of $60 \%$ of unchanged HI- 6 occurred within the first $6 \mathrm{~h}$ (119). PK analysis of obidoxime in human showed that $68-84 \%$ of applied dose was excreted in the urine unchanged within 24 hours $(120,122)$ despite its possible reabsorption in kidneys (122). For TMB-4 in rats, it was also shown that it is eliminated unchanged in urine (106).

The possibility of oximes to be biotransformed by CYP enzymes was tested in several studies. It seems that charged oximes K048 and HI- 6 were not degraded by CYPs (136). As for non-permanently charged and more lipophilic oximes, the study on RS194B showed that the primary route of elimination is via urine, and that it was metabolically stable over the course of the experiment (75). 3-hydroxy-2-pyridine oximes were also shown to be metabolic stable in the liver microsome CYP metabolic degradation assay, with the exception of the highly lipophilic GM508 oxime with a tetrahydroisoquinoline substituent (66).

\section{Plasma protein binding and distribution into tissues}

A study by Ecobichon et al. (117) showed there is no significant plasma protein or tissue protein binding for HI-6. Moreover, Zemek (115) reported no significant binding (1-7\%) of HI-6, obidoxime, or TMB-4 to human serum albumin (HSA). Some charged K-oximes (K027, K075, K127, K203, and K282) also showed a low level of binding to HSA (4-15\%) (115). Therefore, this aspect is not expected to affect the therapeutic efficacy of these or similar oximes, i.e., compounds that are not bound to plasma proteins are free to move within different body compartments and exert different actions.

As for the distribution, 2-PAM showed it diffuses freely across the physiological compartments with a higher apparent volume of distribution $\left(V_{\mathrm{d}}\right)$ than obidoxime in human (122) or than HI-6 in sheep (107) and in human (119). Studies by Garrigue et al. $(106,112)$ demonstrated the highest distribution of 2-PAM and HI-6 to mucopolysaccharide-containing tissues (cartilage, intervertebral disc), kidney, and some distribution to other highly perfused tissues. A study on obidoxime in humans by Thiermann et al. (124) showed distribution and retention in cartilage, kidney and liver; less in the lungs, muscle, hearth, and brain.

Uncharged oximes have not been tested for plasma protein binding; however, from the PK blood profile and short circulation time for 3-hydroxy-2-pyridine oximes it can be concluded that no plasma protein binding took place (66). A study on RS194B in guinea pigs showed rapid and extensive distribution beyond the plasma compartment (75). Highest RS194B concentrations were determined in kidney and liver, followed by lung, spleen, heart and brain tissues (75).

\section{Brain penetration of oximes}

Several in vitro methods, mostly PAMPA or MDCK cell line, were employed in order to test the BBB penetration ability of standard charged oximes and oximes designed for CNS activity and resulting permeability rates are presented in Table 3. From available data, the permeability rate of 3-hydroxy-2-pyridine oximes was significantly higher than that of charged standard oximes. Charged oximes HI-6, 2-PAM and MMB-4 were also classified as impermeable in another PAMPA study (137). Moreover, studies on charged pyridinium oximes showed that their PAMPA permeability was increased with the number of fluorine atoms (83) or chlorine atoms (81) compared to non-substituted analogues. The IAM technique also showed a relatively low predicted permeability value for charged bisquaternary oximes (e.g., HI-6, obidoxime, TMB-4, K-oximes), whereas monoquaternary oximes (2PAM) had higher potential for penetration across the BBB (138). HI-6 encapsulated in nanoparticles showed a 1.5 to 2 times higher transport of the oxime across the in vitro primary porcine brain capillary endothelial cells model compared to the transport of HI-6 alone (89).

In addition, using different MDCK cell lines, it was shown that charged oxime 2-PAM is not a substrate of P-gp or BCRP efflux pumps (139). Moreover, the P-gp 
Table 3. BBB penetration of oximes determined in vitro (permeability rate, $\left.P_{e} / P_{a p p}\right)$ and in vivo (brain/blood ratio).

\begin{tabular}{|c|c|c|c|}
\hline Oxime & $\begin{array}{l}\text { PAMPA } \\
P_{\mathrm{e}}\left(10^{-6} \mathrm{~cm} \mathrm{~s}^{-1}\right)\end{array}$ & $\begin{array}{l}\text { MDCK cell line } \\
P_{\text {app }}\left(10^{-6} \mathrm{~cm} \mathrm{~s}^{-1}\right)\end{array}$ & $\begin{array}{l}\text { In vivo } \\
\left(\left[\text { oxime }_{\text {brain }} /[\text { oxime }]_{\text {blood }}\right) \cdot 100\right.\end{array}$ \\
\hline 2-PAM & $<0.4(75,81,141)$ & $<3(139,141)$ & Rat: $6-10 \%(25,142,143)$ \\
\hline HI-6 & $0.8(81,141)$ & $0(141)$ & Rat: 9-18\% (116), <1\% (144) \\
\hline Obidoxime & 0.7 (141) & $1(141)$ & Mouse, rat: 3-5\% (145); Rat: <1\%(144) \\
\hline TMB-4 & $0.1(141)$ & $0.4(141)$ & Rat: $<1 \%(146)$ \\
\hline Other pyridinium oximes & $<0.5(81)$ & - & Rat: $<1 \%(125,144,146)$ \\
\hline Chloro-pyridinium oximes & $1.0-2.6(81)$ & - & - \\
\hline $\begin{array}{l}\text { 3-hydroxy-2-pyridine oximes } \\
\text { GM415 } \\
\text { JR595 }\end{array}$ & $\begin{array}{l}5-7(141) ; 6-30(64) \\
12(64) \\
6(64)\end{array}$ & $\begin{array}{l}12-32(141) \\
- \\
36(66)^{*}\end{array}$ & $\begin{array}{l}\text { Rat: } 30 \%(67) \\
\text { Mouse: } 40 \%(66)\end{array}$ \\
\hline $\begin{array}{l}\text { 2-hydroxyiminoacetamide oxi } \\
\text { RS41A } \\
\text { RS194B }\end{array}$ & - & n.s. $(75)^{* *}$ & $\begin{array}{l}\text { Mouse: } 12 \%(69) \\
\text { Mouse: } 30 \% \text { (69); Guinea pig: 4-18\% (75) }\end{array}$ \\
\hline
\end{tabular}

efflux pump did not show any affinity for non-permanently charged oximes RS194B and JR595 $(66,75)$ neither. Other study investigated the affinity of the P-gp substrate for a number of substituted phenoxyalkyl pyridinium oximes and tried to correlate it with in vivo oxime efficacy (140).

Standard oximes also showed poor BBB penetration in vivo $(147,148)$ and this was addresses either by determining the brain/blood ratio or by measuring brain ChE reactivation after a defined time of treatment with an oxime. Slight differences in BBB penetration data for an individual oxime are the result of various animal models or methods/techniques used to determine these parameters. Also, oximes clearly achieve different concentrations in different brain regions, and this is one of the possible reasons for the variability between studies that used whole brain or different brain regions to determine an oxime's presence.

More precisely, brain concentrations of 2-PAM in rats were approximately $10 \%$ of blood concentrations (25, 142, 143). Moreover, Sakurada et al. suggests that 2-PAM is actively transported across the $\mathrm{BBB}$ in a $\mathrm{Na}^{+}$-dependent manner (25). Obidoxime application to mice and rats resulted in $3-5 \%$ of blood concentration penetrating into brain (145), while 9-18\% of the plasma HI-6 reached the brain in rats (116). In a study by Joosen et al. (93), brain HI- 6 concentrations were less than $5 \%$ of its blood concentration. Even poorer brain penetration $(<1 \%)$ of HI-6, obidoxime, and TMB-4 in rats was observed in other studies $(144,146)$. As for studies that measured brain ChE reactivation, Clement (149) examined the reactivation of sarin-inhibited ChE in the hypothalamus, hippocampus, and cortex by HI-6, obidoxime, and 2-PAM; only HI-6 showed significant reactivation with highest reactivation in hypothalamus (45\%) relatively to control groups. In rats exposed to OP insecticide, 2-PAM reactivated $12 \%$ of $\mathrm{ChE}$ in the cortex and spinal cord, while at the whole brain level it was $6 \%$ (142). The brain concentrations of other pyridinium oximes (K027, K048, K074) were less than $2 \%$ of their blood concentration (144, 146, 147, 150). K027 achieved the highest concentration in the frontal cortex $>$ pontomedullar area $>$ basal ganglia (125), and the same distribution was observed for TMB-4 and K074 (146).

Studies on the brain penetration of non-permanently charged oxime RS194B in mice showed rapid penetration to the brain amounting to concentrations equal to $30 \%$ of the blood concentration. Moreover, its brain concentrations exceeded blood levels after approximately 30 minutes $(69,76)$. In comparison, the $C_{\max }$ of $\mathrm{RS} 194 \mathrm{~B}$ in the brain of guinea pigs corresponded to $4-18 \%$ of blood concentration across the dose range and the elimination of RS194B from the brain also lagged behind plasma clearance (75). The lead 3-hydroxy-2-pyridine oxime reactivator JR595 achieved maximal brain concentration that corresponded to $40 \%$ of blood concentration 15 min post-application (66). Other 3-hydroxy-2-pyridine oxime, GM415, applied i.v. to rats also achieved the brain concentration of approximately $30 \%$ of blood concentration at 5 minutes, while NP-encapsulated GM415 reached higher brain concentrations that were sustained for a longer time (67). Comparably, 2-PAM in NPs also achieved higher brain concentrations in rats relatively to 2-PAM administered alone (91). In paraoxon-exposed rats, 2-PAM or GM415 administered alone reactivated no or $<5 \%$ of brain AChE, respectively. The same oximes encapsulated in NP reactivated $15 \%$ and $30 \%$ of brain AChE, respectively $(67,91)$.

Also, the administration of an inhibitor of efflux transporter P-gp, tariquidar, resulted in a 2-times higher con- 
centration of HI-6 in the brain of rats pre-treated with HI-6 and poisoned with soman; it also showed a comparable increase in AChE activity (93).

The CNS activity of oximes has also been evaluated by using biomarkers such as neuroprotection or survival. Tertiary oximes MINA and DAM exerted improved survival and prevented of seizures when compared to charged oximes 2-PAM, MMB-4, or HLö-7 in sarin-poisoned guinea pigs, and this was attributed to the reactivation of brain AChE. Brain reactivation by MINA was additionally proved in VX- and cyclosarin-exposed guinea pigs $(58,151)$. A study with the prodrug of 2-PAM (pro-2PAM) showed moderate reactivation of brain AChE and prevention of seizures and neuropathology in guinea pigs exposed to sarin and VX, while it was ineffective for cyclosarin (152). Moreover, a lead charged phenoxyalkyl pyridinium oxime with lipophilic moiety showed brain neuroprotection against sarin and VX surrogates and paraoxon as opposed to no effect with 2-PAM $(79,80)$. Fluoro-pyridinium oxime KR-22836 showed a slightly higher neuroprotective effect than K203 and obidoxime in case of tabun-poisoned rats (153). 3-hydroxy-2-pyridine oxime GM415 encapsulated in NPs achieved higher brain AChE reactivation in rats exposed to paraoxon when compared to the oxime alone (67) and showed potential to provide protection for mice exposed to high doses of VX and sarin (66). JR595 demonstrated potential to attenuate toxic effects in mice exposed to multiple doses of VX and sarin (66).

Finally, it is important to state that some authors reported that the smallest necessary level of AChE activity is as low as $2 \%$ in the pontomedullar area, one of the suggested brain regions critical for survival (154). Others suggested that some of the protective effects of bispyridinium oximes could be attributed to mechanisms other than enzyme reactivation, e.g., interaction with $\mathrm{nAChR}$ and $\mathrm{mAChR}$ receptors at both peripheral and central level (155).

\section{Drug-drug interaction and oxime formulation}

Drug-drug interaction and drug formulation can significantly influence drug PK profile. In the study Lundy et al. (118) it was demonstrated that HI-6 oxime retained the same PK profile when applied along with muscarinic receptor antagonist atropine as without it. This was also observed in studies in man $(119,156)$. Some charged oximes were tested for their inhibitory potential of CYP enzymes, which is one of the mechanisms that can lead to drug-drug interaction by reducing metabolism of coadministered drugs and possibly lead to their prolonged action or toxicity. Oximes K048 and HI-6 showed only a slight inhibitory potential for some members of the CYP family. For example, K048 showed low inhibition of CYP2C19 (20\%) at concentrations $\geq 100 \mu \mathrm{M}$, and up to
$20 \%$ inhibition of CYP2D6 at $400 \mu \mathrm{M}$, while HI-6 inhibited CYP2E1 in a 5-40\% range with concentrations of $10-400 \mu \mathrm{M}$. However, inhibition at these concentrations is probably not clinically significant (136). Similarly, K027 and K203 did not significantly inhibit either of the CYP family members: K203 inhibited 35\% activity of CYP2E1 and up to $20 \%$ of 2C9, 2D6, and $3 \mathrm{~A} 4$ members at high $400 \mu \mathrm{M}$ concentration (157).

The drug formulation or the means of administration are known to affect the PK behaviour of a drug. A study on two different HI-6 salts, dimethanesulfonate and dichloride did not show any significant difference between their PK profiles (118). Chloride and methanesulfonate salts of 2-PAM also show similar PK behaviour after p.o. application in human $(128,129)$. HI-6 application via $i . m$. syringe or i.m. autoinjector also had minor effect on its circulation time (109).

\section{OP exposure can change the pharmacokinetic behaviour of oximes}

In general, PK and PD of a drug can be influenced by the possible pathophysiological changes in an organism. Studies have shown that poisoning with OPs can influence the blood flow and PK behaviour of oximes. Maxwell et al. (158) showed that soman reduces the kidney blood flow which can reduce the renal excretion of oximes. Studies by Garrigue et al. $(106,112)$ showed that soman did not show significant change of plasma PK for neither HI-6 or 2-PAM, while OP compound A4 increased blood concentrations for the lower doses of both oximes $(106,112)$. In addition, Cassel et al. (116) showed that soman poisoning in rats resulted with a higher HI-6 blood concentration over time when it was administered at a higher dose $(100 \mathrm{mg} / \mathrm{kg})$ probably due to reduced renal secretion (116), while at concentrations $\leq 75 \mathrm{mg} / \mathrm{kg}$ there was no significant change of HI-6 blood concentration between soman-exposed and control rats (116). Therefore, the influence of OPs on PK of oximes should be taken into account when considering the duration of the oximes effect, but also when considering oximes that could exert serious side-effects because of their prolonged circulation time and slow elimination. Kušić et al. (119) study reported no side-effects of HI-6 in man. Moreover, Clement et al. (156) demonstrated that HI-6 reduce adverse drug experiences caused by atopine alone. However, a dose-dependent mild to moderate transient side-effects of 2-PAM (diarrhea, dizziness, blurred vision, diplopia) $(110,128)$ and obidoxime (face muscles paresthesia, cool sensation in mouth, heavy eyes, blood pressure and heart rate change, nausea, vomiting) $(120,131)$ were observed in man. Moreover, a product in reactivation reaction with charged pyridine oximes is phosphonyl oxime that can re-inhibit $\mathrm{AChE}$ and possibly reduce the antidotal potency of applied therapy or cause other side-effects (159). With that in mind, the generally observed fast elimination of oximes and/or phosphonyl oximes is a beneficial characteristic. 
Furthermore, BBB permeability was shown to be temporarily or permanently changed in many pathological CNS conditions (e.g., multiple sclerosis, hypoxia, ischemia, oedema, Parkinson's or Alzheimer's disease, epilepsy, tumours, glaucoma, lysosomal storage diseases) or in diseases that originate outside the CNS (e.g., HIV infection, diabetes, etc.) $(33,36)$. Since human brain microvessels and astroglia express muscarinic receptors, $\mathrm{ACh}$ is involved in the cortical perfusion (160) and ACh overstimulation in $\mathrm{OP}$ poisoning can change the $\mathrm{BBB}$ permeability. Increased blood flow in brain was observed in soman-poisoned rats (158), and other study showed that soman induced an increase of BBB permeability in rats without seizures (161). Similarly, Scremin et al. (162) showed an increase in regional cerebral blood flow in rats exposed to low level sarin. In addition, BBB permeability change and disruption was observed in a transcriptomic study in rats after sarin exposure through change in gene expression that indicates a disturbance of normal oligodendrocyte and BBB function (22). Finally, a study by Cassel et al. (116) demonstrated lower brain-uptake of oxime HI-6 in soman-exposed rats and the authors suggested that this could be the result of the soman-induced vasoconstriction of the capillaries in the $\mathrm{BBB}$ or a depressing effect on blood pressure. A study in rats exposed to paraoxon did not show relevant changes in brain concentrations of 2-PAM compared to non-exposed rats (143). The brain 2-PAM concentration was not different in non-exposed vs. soman-exposed rats, while HI-6 achieved slightly higher concentrations in somanand A4-exposed rats compared to control animals (106, 112). Therefore, the possibility of $\mathrm{BBB}$ change upon $\mathrm{OP}$ exposure when predicting the brain concentrations of oximes should be taken into account.

Finally, the change in mucus production after exposure to OPs could affect the oxime absorption in case of its intranasal application. More precisely, the rhinorrhea is one of the first symptoms even at exposure to low OP doses (163) while some studies showed that allergic or viral rhinitis could affect nasal absorption (103).

\section{CONCLUDING REMARKS}

Brain oxime activity and the necessity of brain ChE reactivation is still a controversial subject as some authors reported that relatively low oxime penetration to the brain could elicit pharmacological effects. Additional point is that antimuscarinic activity of atropine could minimize most of OP poisoning symptoms; however, nicotinic effects are only addressed indirectly by the oxime reactivation of inhibited AChE. The influence of reactivation of brain ChE in the survival and/or neuroprotection in OPexposed animals was demonstrated after treatment with non-permanently charged tertiary oximes with improved BBB penetration potency. Nevertheless, newly designed oximes are usually evaluated for their reactivation potency in vitro by determining their reactivation potency.
It is generally known that the PD parameters defined in a closed system at equilibrium in vitro does not properly reflect the potency in vivo where the oxime concentration at the target site is under constant change and is influenced by numerous factors. However, in silico, in vitro, and ex vivo methods serve to detect potential drawbacks early in the pre-clinical studies.

The main predisposition of an oxime's central activity is the sufficiently long exposure of AChE in the synapses of peripheral and central nervous system to the effective concentrations of unbound active form of an oxime. Therefore, evaluating the PK and neuropharmacokinetics behaviour of oximes is a crucial step in obtaining a clearer picture of an oxime's antidotal potency. High-throughput assays are useful in characterizing individual PK descriptors such as BBB penetration, metabolic stability, plasma and tissue protein binding, etc. that can give a glimpse into a target site exposure to an oxime and help determine the lead compound for further in vivo evaluation. Certainly, in vivo studies enable assessment of a full concentration-time profile of an administrated oxime dose in blood and brain. Simultaneously, different PD markers such as survival and neuroprotection can be addressed in OP-poisoned animals treated with an oxime.

An unfavourable outcome can be improved by changing the dosage regime or by improving oxime formulations. Since the main drawback of both charged and nonpermanently charged oximes seems to be their short circulation time, this should be addressed by either repeated administration of an oxime or by the application of an i.v. infusion. Future improvements in that regard are expected with the enforcement of NP-encapsulated drugs that would serve to prolong circulation time and brain targeting. Additional possibility with NPs is the encapsulation and delivery of more than one active compound, which is especially interesting for yielding a potent reactivation for a broad spectrum of OPs. Also, the firstaid autoinjector for treatment of OP poisoning includes both atropine and an oxime. Therefore, possible drugdrug interactions along with pathophysiological changes elicited by OP should be accounted in the evaluation of the overall antidotal treatment.

In conclusion, defining the PK-PD relationship of different oxime candidates would help generate databases and models that would help estimate the in vivo behaviour of an oxime based on its molecular properties as well as for translation from animal studies to humans. Gathering such information and taking them into consideration might greatly improve future design and development of novel antidotes.

Acknowledgements: We thank Makso Herman for language editing. Graphics from Servier medical art were used for the figures. Supported by the Croatian Science Foundation (IP-2013-11-4307 and IP-2018-01-7683). 


\section{REFERENCES}

1. https://www.who.int/features/qa/55/en/; March 2020.

2. https://www.who.int/ipcs/publications/pesticides_hazard/en/; March 2020.

3. https://ec.europa.eu/food/plant/pesticides/eu-pesticides-database/ public/?event=homepage\&language=EN; March 2020.

4. BUCKLEY NA, KARALLIEDDE L, DAWSON A, SENANAYAKE N, EDDLESTON M 2004 Where is the evidence for treatments used in pesticide poisoning? Is clinical toxicology fiddling while the developing world burns? J Toxicol Clin Toxicol 42(1): 113-116 https://doi.org/10.1081/CLT-120028756

5. EDDLESTON M and CHOWDHURY FR 2016 Pharmacological treatment of organophosphorus insecticide poisoning: the old and the (possible) new. Br J Clin Pharmacol 81(3): 462-470 https://doi.org/10.1111/bcp.12784

6. YANAGISAWA N, MORITA H, NAKAJIMA T 2006 Sarin experiences in Japan: Acute toxicity and long-term effects. J Neurol Sci 249(1): 76-85 https://doi.org/10.1016/j.jns.2006.06.007

7. JOHN H, VAN DER SCHANS MJ, KOLLER M, SPRUIT HET, WOREK F, THIERMANN H, NOORT D 2018 Fatal sarin poisoning in Syria 2013: forensic verification within an international laboratory network. Forensic Toxicol 360(1): 61-71 https://doi.org/10.1007/s11419-017-0376-7

8. https://www.opcw.org/media-centre/news/2017/02/statementopcw-spokesperson-response-media-queries-regarding-allegeduse; March 2020.

9. KLOSKE M, WITKIEWICZ Z 2019 Novichoks - The A group of organophosphorus chemical warfare agents. Chemosphere 221: 672-682 https://doi.org/10.1016/j.chemosphere.2019.01.054

10. STONE R 2018 U.K. attack puts nerve agent in the spotlight. Science 359(6382): 1314-1315

https://doi.org/10.1126/science.359.6382.1314

11. HARALD J, BALSZUWEIT F, KEHE K, WOREK F, THIERMANN H 2015 Toxicokinetic aspect of nerve agent and vesicants, In: Gupta R C (ed) Handbook of Toxicology of Chemical Warfare Agents, Academic Press, Cambridge, Massachusetts, USA, p 817 https:/doi.org/10.1016/B978-0-12-800159-2.00056-7

12. DARVESH S, HOPKINS DA, GEULA C 2003 Neurobiology of butyrylcholinesterase. Nat Rev Neurosci 4(2): 131-138 https://doi.org/10.1038/nrn1035

13. ROMANO JA, MCDONOUGH JH, SHERIDAN R, SIDELL F 2001 Health effects of low-level exposure to nerve agents, In: Somani S and Romano J A (eds) Chemical Warfare Agents: Toxicity at Low Levels, CRC Press, Boca Raton, p 1

14. SHIH T-M, DUNIHO SM, MCDONOUGH JH 2003 Control of nerve agent-induced seizures is critical for neuroprotection and survival. Toxicol Appl Pharmacol 188(2): 69-80 https://doi.org/10.1016/S0041-008X(03)00019-X

15. KADAR T, SHAPIRA S, COHEN G, SAHAR R, ALKALAY D, RAVEH L 1995 Sarin-induced neuropathology in rats. Hum Exp Toxicol 14(3): 252-259 https://doi.org/10.1177/096032719501400304

16. MCDONALD BE, COSTA LG, MURPHY SD 1988 Spatial memory impairment and central muscarinic receptor loss following prolonged treatment with organophosphates. Toxicol Lett 40(1): 47-56 https://doi.org/10.1016/0378-4274(88)90182-8

17. KASSA J, BAJGAR J, KUCA K, JUN D 2015 Behavioral toxicity of nerve agents, In: Gupta R C (ed) Handbook of Toxicology of Chemical Warfare Agents, Elsevier, p 477 https://doi.org/10.1016/B978-0-12-800159-2.00035-X

18. LIU J, UCHEA C, WRIGHT L, POPE C 2015 Chemical warfare agents and the nervous system, In: Gupta R C (ed) Handbook of Toxicology of Chemical Warfare Agents, Elsevier, p 463 https://doi.org/10.1016/B978-0-12-800159-2.00034-8
19. MCDONOUGH JH, SHIH T-M 1997 Neuropharmacological mechanisms of nerve agent-induced seizure and neuropathology. Neurosci Biobehav Rev 21(5): 559-579 https://doi.org/10.1016/S0149-7634(96)00050-4

20. KAUR S, SINGH S, CHAHAL KS, PRAKASH A 2014 Potential pharmacological strategies for the improved treatment of organophosphate-induced neurotoxicity. Can J Physiol Pharmacol 92(11): 893-911 https://doi.org/10.1139/cjpp-2014-0113

21. PACHIAPPAN A, THWIN MM, WENG KEONG L, LEE FK, MANIKANDAN J, SIVAKUMAR V, GOPALAKRISHNAKONE P 2009 ETS2 Regulating neurodegenerative signaling pathway of human neuronal (SH-SY5Y) cells exposed to single and repeated low-dose sarin (GB). Chem Res Toxicol 22(6): 990-996 https://doi.org/10.1021/tx8003467

22. DAMODARAN TV, GREENFIELD ST, PATEL AG, DRESSMAN HK, LIN SK, ABOU-DONIA MB 2006 Toxicogenomic studies of the rat brain at an early time point following acute sarin exposure. Neurochem Res 31(3): 367-381

https://doi.org/10.1007/s11064-005-9023-5

23. SPRADLING KD, LUMLEY LA, ROBISON CL, MEYERHOFF JL, DILLMAN JF 2011 Transcriptional responses of the nerve agent-sensitive brain regions amygdala, hippocampus, piriform cortex, septum, and thalamus following exposure to the organophosphonate anticholinesterase sarin. J Neuroinflammation 8(1): 84 https://doi.org/10.1186/1742-2094-8-84

24. DILLMAN JF, PHILLIPS CS, KNIFFIN DM, TOMPKINS CP, HAMILTON TA, KAN RK 2009 Gene expression profiling of rat hippocampus following exposure to the acetylcholinesterase inhibitor soman. Chem Res Toxicol 22(4): 633-638 https://doi.org/10.1021/tx800466v

25. SAKURADA K, MATSUBARA K, SHIMIZU K, SHIONO H, SETO Y, TSUGE K, YOSHINO M, SAKAI I, MUKOYAMA H, TAKATORI T 2003 Pralidoxime Iodide (2-PAM) Penetrates across the Blood-Brain Barrier. Neurochem Res 28(9): 1401-1407 https://doi.org/10.1023/A:1024960819430

26. CASSEL G, KARLSSON L, WAARA L, ANG KW, GÖRANSSON-NYBERG A 1997 Pharmacokinetics and effects of HI-6 in blood and brain of soman-intoxicated rats: A microdialysis study. Eur J Pharmacol 332(1): 43-52 https://doi.org/10.1016/S0014-2999(97)01058-3

27. KALÁSZ H, NURULAIN SM, VERESS G, ANTUS S, DARVAS F, ADEGHATE E, ADEM A, HASHEMI F, TEKES K 2015 Mini review on blood-brain barrier penetration of pyridinium aldoximes. J Appl Toxicol 35(2): 116-123 http://doi.wiley.com/10.1002/jat.3048

28. LORKE D, KALASZ H, PETROIANU G, TEKES K 2008 Entry of oximes into the brain: A review. Curr Med Chem 15(8): 743-753 https://doi.org/10.2174/092986708783955563

29. LEWIS DFV, JACOBS MN, DICKINS M 2004 Compound lipophilicity for substrate binding to human P450s in drug metabolism. Drug Discov Today 9(12): 530-537 https://doi.org/10.1016/S1359-6446(04)03115-0

30. KOVARIK Z, ČALIĆ M, BOSAK A, ŠINKO G, JELIĆ D 2008 In vitro evaluation of aldoxime interactions with human acetylcholinesterase. Croat Chem Acta 81(1): 47-57 https://hrcak.srce.hr/23385

31. MAČEK HRVAT N, ZORBAZ T, ŠINKO G, KOVARIK Z 2018 The estimation of oxime efficiency is affected by the experimental design of phosphylated acetylcholinesterase reactivation. Toxicol Lett 293: 222-228 https://doi.org/10.1016/j.toxlet.2017.11.022

32. PALMER AM, ALAVIJEH MS 2013 Overview of experimental models of the blood-brain barrier in CNS drug discovery. Curr Protoc Pharmacol 62(1): 7.15.1-7.15.30 https://doi.org/10.1002/0471141755.ph0715s62 
33. ABBOTT NJ, PATABENDIGE AAK, DOLMAN DEM, YUSOF SR, BEGLEY DJ 2010 Structure and function of the bloodbrain barrier. Neurobiol Dis 37(1): 13-25 https://doi.org/10.1016/J.NBD.2009.07.030

34. BEGLEY DJ 2004 Delivery of therapeutic agents to the central nervous system: the problems and the possibilities. Pharmacol Ther 104(1): 29-45 https://doi.org/10.1016/j.pharmthera.2004.08.001

35. LAKSITORINI M, PRASASTY VD, KIPTOO PK, SIAHAAN TJ 2014 Pathways and progress in improving drug delivery through the intestinal mucosa and blood-brain barriers. Ther Deliv 5(10): 1143-1163 https://doi.org/10.4155/tde.14.67

36. ABBOTT N J 2013 Blood-brain barrier structure and function and the challenges for CNS drug delivery. J Inherit Metab Dis 36(3): 437-449 https://doi.org/10.1007/s10545-013-9608-0

37. DE LANGE ECM, VAN DEN BRINK W, YAMAMOTO Y, DE WITTE WEA, WONG YC 2017 Novel CNS drug discovery and development approach: model-based integration to predict neuropharmacokinetics and pharmacodynamics. Expert Opin Drug Discov 12(12): 1207-1218

https://oi.org/10.1080/17460441.2017.1380623

38. LI X, YU B, SUN Q, ZHANG Y, REN M, ZHANG X, LI A, YUAN J, MADISEN L, LUO Q, ZENG H, GONG H, QIU Z 2018 Generation of a whole-brain atlas for the cholinergic system and mesoscopic projectome analysis of basal forebrain cholinergic neurons. Proc Natl Acad Sci U S A 115(2): 415-420 https://doi.org/10.1073/pnas.1703601115

39. SHIH T-M, SKOVIRA J W, O'DONNELL JC, MCDONOUGH $\mathrm{JH} 2010$ In vivo reactivation by oximes of inhibited blood, brain and peripheral tissue cholinesterase activity following exposure to nerve agents in guinea pigs. Chem Biol Interact 187(1-3): 207-214 https://doi.org/10.1016/j.cbi.2010.03.006

40. RANKOVIĆ Z 2015 CNS drug design: Balancing physicochemical properties for optimal brain exposure. J Med Chem 58(6): 2584-2608 https://doi.org/10.1021/jm501535r

41. LIPINSKI CA, LOMBARDO F, DOMINY BW, FEENEY PJ 1997 Experimental and computational approaches to estimate solubility and permeability in drug discovery and development settings. Adv Drug Deliv Rev 23: 3-25 https://doi.org/10.1016/S0169-409X(00)00129-0

42. PAJOUHESH H and LENZ GR 2005 Medicinal chemical properties of successful central nervous system drugs. J Am Soc Exp Neurother 2: 541-553 https://doi.org/10.1602/neurorx.2.4.541

43. WAGER TT, HOU X, VERHOEST PR, VILLALOBOS A 2010 Moving beyond rules: the development of a central nervous system multiparameter optimization (CNS MPO) approach to enable alignment of druglike properties. ACS Chem Neurosci 1(6): 435 49 https://doi.org/10.1021/cn100008c

44. WAGER TT, HOU X, VERHOEST PR, VILLALOBOS A 2016 Central nervous system multiparameter optimization desirability: Application in drug discovery. ACS Chem Neurosci 7(6): 767-775 https://doi.org/10.1021/acschemneuro.6b00029

45. RANKOVIĆ Z 2017 CNS Physicochemical property space shaped by a diverse set of molecules with experimentally determined exposure in the mouse brain. J Med Chem 60(14): 5943-5954 https://doi.org/10.1021/acs.jmedchem.6b01469

46. DI L, KERNS EH, FAN K, MCCONNELL OJ, CARTER GT 2003 High throughput artificial membrane permeability assay for blood-brain barrier. Eur J Med Chem 38(3): 223-232 https://doi.org/10.1016/S0223-5234(03)00012-6

47. TSINMAN O, TSINMAN K, SUN N, AVDEEF A 2011 Physicochemical selectivity of the BBB microenvironment governing passive diffusion-Matching with a porcine brain lipid extract artificial membrane permeability model. Pharm Res 28(2): 337363 https://doi.org/10.1007/s11095-010-0280-x
48. YOON CH, KIM SJ, SHIN BS, LEE KC, YOO SD 2006 Rapid screening of blood-brain barrier penetration of drugs using the immobilized artificial membrane phosphatidylcholine column chromatography. J Biomol Screen 11(1): 13-20 https://doi.org/10.1177/1087057105281656

49. HELMS HC, ABBOTT NJ, BUREK M, CECCHELLI R, COURAUD P-O, DELI M A, FÖRSTER C, GALLA HJ, ROMERO IA, SHUSTA EV, STEBBINS MJ, VANDENHAUTE E, WEKSLER B, BRODIN B 2016 In vitro models of the bloodbrain barrier: An overview of commonly used brain endothelial cell culture models and guidelines for their use. J Cereb Blood Flow Metab 36(5): 862-890 https://doi.org/10.1177/0271678X16630991

50. LIPPMANN ES, AZARIN SM, KAY JE, NESSLER RA, WILSON HK, AL-AHMAD A, PALECEK SP, SHUSTA EV 2012 Derivation of blood-brain barrier endothelial cells from human pluripotent stem cells. Nat Biotechnol 30(8): 783-791 https://doi.org/10.1038/nbt.2247

51. WANG Q, RAGER JD, WEINSTEIN K, KARDOS PS, DOBSON GL, LI J, HIDALGO IJ 2005 Evaluation of the MDRMDCK cell line as a permeability screen for the blood-brain barrier. Int J Pharm 288(2): 349-359

https://doi.org/10.1016/j.ijpharm.2004.10.007

52. FRIDÉN M, BERGSTRÖM F, WAN H, REHNGREN M, AHLIN G, HAMMARLUND-UDENAES M, BREDBERG U 2011 Measurement of unbound drug exposure in brain: Modeling of $\mathrm{pH}$ partitioning explains diverging results between the brain slice and brain homogenate methods. Drug Metab Dispos 39(3): 353-362 https://doi.org/10.1124/dmd.110.035998

53. DARVESH AS, CARROLL RT, GELDENHUYS WJ, GUDELSKY GA, KLEIN J, MESHUL CK, VAN DER SCHYF CJ 2011 In vivo brain microdialysis: advances in neuropsychopharmacology and drug discovery. Expert Opin Drug Discov 6(2): 109-127 https://doi.org/10.1517/17460441.2011.547189

54. KULKARNI AD, PATEL HM, SURANA SJ, BELGAMWAR VS, PARDESHI CV. 2016 Brain-blood ratio: implications in brain drug delivery. Expert Opin Drug Deliv 13(1): 85-92 https://doi.org/10.1517/17425247.2016.1092519

55. REICHEL A 2009 Addressing central nervous system (CNS) penetration in drug discovery: Basics and implications of the evolving new concept. Chem Biodivers 6(11): 2030-2049 https://doi.org/10.1002/cbdv.200900103

56. DE LANGE ECM 2015 PBPK modeling approach for predictions of human CNS drug brain distribution, In: Di L and Kerns E H (eds) Blood-Brain Barrier in Drug Discovery: Optimizing Brain Exposure of CNS Drugs and Minimizing Brain Side Effects for Peripheral Drugs, John Wiley \& Sons, Inc., p 296 https://doi.org/10.1002/9781118788523.ch14

57. CHILDS AF, DAVIES DR, GREEN AL, RUTLAND JP 1955 The reactivation by oximes and hydroxamic acids of cholinesterase inhibited by organo-phosphorus compounds. Br J Pharmacol Chemother 10(4): 462-5 https://doi.org/10.1111/j.1476-5381.1955.tb00106.x

58. SKOVIRA JW, O'DONNELL JC, KOPLOVITZ I, KAN RK, MCDONOUGH JH, SHIH T-M 2010 Reactivation of brain acetylcholinesterase by monoisonitrosoacetone increases the therapeutic efficacy against nerve agents in guinea pigs. Chem Biol Interact 187(1-3): 318-324 https://doi.org/10.1016/J.CBI.2010.03.010

59. MERCEY G, VERDELET T, SAINT-ANDRÉ G, GILLON E, WAGNER A, BAATI R, JEAN L, NACHON F, RENARD P-Y 2011 First efficient uncharged reactivators for the dephosphylation of poisoned human acetylcholinesterase. Chem Commun 47(18): 5295 https://doi.org/10.1039/c1cc10787a

60. MERCEY G, RENOU J, VERDELET T, KLIACHYNA M, BAATI R, GILLON E, ARBOLÉAS M, LOIODICE M, NACHON F, JEAN L, RENARD P-Y 2012 Phenyltetrahydroisoquinoline-pyridinaldoxime conjugates as efficient uncharged reactivators for the 
dephosphylation of inhibited human acetylcholinesterase. J Med Chem 55(23): 10791-10795 https://doi.org/10.1021/jm3015519

61. RENOU J, LOIODICE M, ARBOLÉAS M, BAATI R, JEAN L, NACHON F, RENARD P-Y 2014 Tryptoline-3-hydroxypyridinaldoxime conjugates as efficient reactivators of phosphylated human acetyl and butyrylcholinesterases. Chem Commun 50(30): 3947-3950 https://doi.org/10.1039/C4CC00561A

62. RENOU J, DIAS J, MERCEY G, VERDELET T, ROUSSEAU C, GASTELLIER A-J, ARBOLÉAS M, TOUVREY-LOIODICE M, BAATI R, JEAN L, NACHON F, RENARD P-Y 2016 Synthesis and in vitro evaluation of donepezil-based reactivators and analogues for nerve agent-inhibited human acetylcholinesterase. RSC Adv 6(22): 17929-17940

https://doi.org/10.1039/C5RA25477A

63. KLIACHYNA M, SANTONI G, NUSSBAUM V, RENOU J, SANSON B, COLLETIER J-P, ARBOLÉAS M, LOIODICE M, WEIK M, JEAN L, RENARD P-Y, NACHON F, BAATI R 2014 Design, synthesis and biological evaluation of novel tetrahydroacridine pyridine-aldoxime and -amidoxime hybrids as efficient uncharged reactivators of nerve agent-inhibited human acetylcholinesterase. Eur J Med Chem 78: 455-467

https://doi.org/10.1016/j.ejmech.2014.03.044

64. ZORBAZ T, BRAÏKI A, MARAKOVIĆ N, RENOU J, DE LA MORA E, MAČEK HRVAT N, KATALINIĆ M, SILMAN I, SUSSMAN JL, MERCEY G, GOMEZ C, MOUGEOT R, PÉREZ B, BAATI R, NACHON F, WEIK M, JEAN L, KOVARIK Z, RENARD P-Y 2018 Potent 3-hydroxy-2-pyridine aldoxime reactivators of organophosphate-inhibited cholinesterases with predicted blood-brain barrier penetration. Chem Eur J 24: 9675-9691 https://doi.org/10.1002/chem.201801394

65. CALAS AG, DIAS J, ROUSSEAU C, ARBOLÉAS M, TOUVREY-LOIODICE M, MERCEY G, JEAN L, RENARD PY, NACHON F 2017 An easy method for the determination of active concentrations of cholinesterase reactivators in blood samples: Application to the efficacy assessment of non quaternary reactivators compared to HI-6 and pralidoxime in VX-poisoned mice. Chem Biol Interact 267: 11-16 https://doi.org/10.1016/j.cbi.2016.03.009

66. ZORBAZ T, MIŠETIĆ P, PROBST N, ŽUNEC S, ZANDONA A, MENDAŠ G, MICEK V, MAČEK HRVAT N, KATALINIĆ M, BRAÏKI A, JEAN L, RENARD P-Y, GABELICA MARKOVIĆ V, KOVARIK Z 2020 Pharmacokinetic evaluation of brain penetrating morpholine-3-hydroxy-2-pyridine oxime as an antidote for nerve agent poisoning. ACS Chem Neurosci 11(7): 1072-1084 https://doi.org/10.1021/acschemneuro.0c00032

67. PASHIROVA TN, BRAÏKI A, ZUEVA IV, PETROV KA, BABAEV VM, BURILOVA EA, SAMARKINA DA, RIZVANOV IK, SOUTO EB, JEAN L, RENARD P-Y, MASSON P, ZAKHAROVA LY, SINYASHIN OG 2018 Combination delivery of two oxime-loaded lipid nanoparticles: Time-dependent additive action for prolonged rat brain protection. J Control Release 290: 102-111 https://doi.org/10.1016/j.jconrel.2018.10.010

68. SIT R K, RADIĆ Z, GERARDI V, ZHANG L, GARCIA E, KATALINIĆ M, AMITAI G, KOVARIK Z, FOKIN VV, SHARPLESS KB, TAYLOR P 2011 New structural scaffolds for centrally acting oxime reactivators of phosphylated cholinesterases. J Biol Chem 286(22): 19422-19430

https://doi.org/10.1074/jbc.M111.230656

69. RADIĆ Z, SIT RK, KOVARIK Z, BEREND S, GARCIA E, ZHANG L, AMITAI G, GREEN C, RADIĆ B, FOKIN VV, SHARPLESS KB, TAYLOR P 2012 Refinement of structural leads for centrally acting oxime reactivators of phosphylated cholinesterases. J Biol Chem 287(15): 11798-11809 https://doi.org/10.1074/jbc.M111.333732

70. KOVARIK Z, MAČEK N, SIT RK, RADIĆ Z, FOKIN VV, SHARPLESS KB, TAYLOR P 2013 Centrally acting oximes in reactivation of tabun-phosphoramidated $\mathrm{AChE}$. Chem Biol Interact 203(1): 77-80 https://doi.org/10.1016/j.cbi.2012.08.019

71. RADIĆ Z, SIT RK, GARCIA E, ZHANG L, BEREND S, KOVARIK Z, AMITAI G, FOKIN VV, SHARPLESS KB, TAYLOR P 2013 Mechanism of interaction of novel uncharged, centrally active reactivators with OP-hAChE conjugates. Chem Biol Interact 203(1): 67-71 https://doi.org/10.1016/j.cbi.2012.08.014

72. SIT R K, FOKIN VV, AMITAI G, SHARPLESS KB, TAYLOR P, RADIĆ Z 2014 Imidazole aldoximes effective in assisting butyrylcholinesterase catalysis of organophosphate detoxification. J Med Chem 57(4): 1378-1389 https://doi.org/10.1021/jm401650z

73. ROSENBERG YJ, MAO L, JIANG X, LEES J, ZHANG L, RADIĆ Z, TAYLOR P 2017 Post-exposure treatment with the oxime RS194B rapidly reverses early and advanced symptoms in macaques exposed to sarin vapor. Chem Biol Interact 274: 50-57 https://doi.org/10.1016/J.CBI.2017.07.003

74. ROSENBERG YJ, WANG J, OOMS T, RAJENDRAN N, MAO L, JIANG X, LEES J, URBAN L, MOMPER JD, SEPULVEDA Y, SHYONG Y-J, TAYLOR P 2018 Post-exposure treatment with the oxime RS194B rapidly reactivates and reverses advanced symptoms of lethal inhaled paraoxon in macaques. Toxicol Lett 293: 229-234 https://doi.org/10.1016/J.TOXLET.2017.10.025

75. MALFATTI MA, ENRIGHT HA, BE NA, KUHN EA, HOK S, MCNERNEY MW, LAO V, NGUYEN TH, LIGHTSTONE FC, CARPENTER TS, BENNION BJ, VALDEZ CA 2017 The biodistribution and pharmacokinetics of the oxime acetylcholinesterase reactivator RS194B in guinea pigs. Chem Biol Interact 277: 159-167 https://doi.org/10.1016/j.cbi.2017.09.016

76. SIT R K, KOVARIKZ, MAČEK HRVAT N, ŽUNEC S, GREEN C, FOKIN VV., SHARPLESS KB, RADIĆ Z, TAYLOR P 2018 Pharmacology, pharmacokinetics, and tissue disposition of zwitterionic hydroxyiminoacetamido alkylamines as reactivating antidotes for organophosphate exposure. J Pharmacol Exp Ther 367(2): 363-372 https://doi.org/10.1124/jpet.118.249383

77. YERRI J, BAATI R 2018 Sonogashira reaction of bromofluoropyridinaldoxime nuclei: Convergent synthesis of functionalized 2- and 3-fluoropyridine scaffolds. European J Org Chem 2018(30): 4161-4165 https://doi.org/10.1002/ejoc.201800608

78. CHAMBERS JE, CHAMBERS HW, MEEK EC, PRINGLE RB 2013 Testing of novel brain-penetrating oxime reactivators of acetylcholinesterase inhibited by nerve agent surrogates. Chem Biol Interact 203(1): 135-138 https://doi.org/10.1016/j.cbi.2012.10.017

79. DAIL MB, LEACH CA, MEEK EC, OLIVIER AK, PRINGLE RB, GREEN CE, CHAMBERS JE 2019 Novel brain-penetrating oxime acetylcholinesterase reactivators attenuate organophosphateinduced neuropathology in the rat hippocampus. Toxicol Sci 169(2): 465-474 https://doi.org/10.1093/toxsci/kfz060

80. PRINGLE RB, MEEK EC, CHAMBERS HW, CHAMBERS JE 2018 Neuroprotection from organophosphate-induced damage by novel phenoxyalkyl pyridinium oximes in rat brain. Toxicol Sci 166(2): 420-427 https://doi.org/10.1093/toxsci/kfy212

81. ZORBAZT, MALINAK D, MARAKOVICN, MAČEK HRVAT N, ZANDONA A, NOVOTNY M, SKARKA A, ANDRYS R, BENKOVA M, SOUKUP O, KATALINIĆ M, KUCA K, KOVARIK Z, MUSILEK K 2018 Pyridinium oximes with orthopositioned chlorine moiety exhibit improved physicochemical properties and efficient reactivation of human acetylcholinesterase inhibited by several nerve agents. J Med Chem 61(23): 1075310766 https://doi.org/10.1021/acs.jmedchem.8b01398

82. ZORBAZT, MALINAK D, KUCA K, MUSILEK K, KOVARIK Z 2019 Butyrylcholinesterase inhibited by nerve agents is efficiently reactivated with chlorinated pyridinium oximes. Chem Biol Interact 307: 16-20 https://doi.org/10.1016/j.cbi.2019.04.020

83. JEONG HC, PARK N-J, CHAE CH, MUSILEK K, KASSA J, KUCA K, JUNG Y-S 2009 Fluorinated pyridinium oximes as potential reactivators for acetylcholinesterases inhibited by para- 
oxon organophosphorus agent. Bioorg Med Chem 17(17): 62136217 https://doi.org/10.1016/J.BMC.2009.07.043

84. JEONG HC, KANG NS, PARK N-J, YUM EK, JUNG Y-S 2009 Reactivation potency of fluorinated pyridinium oximes for acetylcholinesterases inhibited by paraoxon organophosphorus agent. Bioorg Med Chem Lett 19(4): 1214-1217 https://doi.org/10.1016/J.BMCL.2008.12.070

85. DEMAR JC, CLARKSON ED, RATCLIFFE RH, CAMPBELL AJ, THANGAVELU SG, HERDMAN CA, LEADER H, SCHULZ SM, MAREK E, MEDYNETS MA, KU TC, EVANS SA, KHAN FA, OWENS RR, NAMBIAR MP, GORDON RK 2010 Pro-2-PAM therapy for central and peripheral cholinesterases. Chem Biol Interact 187(1-3): 191-198 https://doi.org/10.1016/J.CBI.2010.02.015

86. GARCIA GE, CAMPBELL AJ, OLSON J, MOORAD-DOCTOR D, MORTHOLE VI 2010 Novel oximes as blood-brain barrier penetrating cholinesterase reactivators. Chem Biol Interact 187(1-3): 199-206 https://doi.org/10.1016/J.CBI.2010.02.033

87. BHONSLE JB, CAUSEY R, OYLER BL, BARTOLUCCI C, LAMBA D, PESARESI A, BHAMARE NK, SOOJHAWON I, GARCIA GE 2013 Evaluation and computational characterization of the facilitated transport of Glc carbon C-1 oxime reactivators across a blood brain barrier model. Chem Biol Interact 203(1): 129-134 https://doi.org/10.1016/j.cbi.2012.09.012

88. WAGNER $S$, KUFLEITNER J, ZENSI A, DADPARVAR M, WIEN S, BUNGERT J, VOGEL T, WOREK F, KREUTER J, VON BRIESEN H 2010 Nanoparticulate transport of oximes over an in vitro blood-brain barrier model. PLoS One 5(12): e14213 https://doi.org/10.1371/journal.pone.0014213

89. DADPARVAR M, WAGNER S, WIEN S, KUFLEITNER J, WOREK F, VON BRIESEN H, KREUTER J 2011 HI 6 human serum albumin nanoparticles-Development and transport over an in vitro blood-brain barrier model. Toxicol Lett 206(1): 60-66 https://doi.org/10.1016/j.toxlet.2011.06.027

90. KUFLEITNER J, WAGNER S, WOREK F, VON BRIESEN H, KREUTER J 2010 Adsorption of obidoxime onto human serum albumin nanoparticles: Drug loading, particle size and drug release. J Microencapsul 27(6): 506-513

https://doi.org/10.3109/02652041003681406

91. PASHIROVA TN, ZUEVA IV, PETROV KA, BABAEV VM, LUKASHENKO SS, RIZVANOV IK, SOUTO EB, NIKOLSKY EE, ZAKHAROVA LY, MASSON P, SINYASHIN OG 2017 Nanoparticle-delivered 2-PAM for rat brain protection against paraoxon central toxicity. ACS Appl Mater Interfaces 9(20): 16922-16932 https://doi.org/10.1021/acsami.7b04163

92. LAM FC, MORTON SW, WYCKOFF J, VU HAN T-L, HWANG MK, MAFFA A, BALKANSKA-SINCLAIR E, YAFFE MB, FLOYD SR, HAMMOND PT 2018 Enhanced efficacy of combined temozolomide and bromodomain inhibitor therapy for gliomas using targeted nanoparticles. Nat Commun 9(1): 1991 https://doi.org/10.1038/s41467-018-04315-4

93. JOOSEN MJA, VAN DER SCHANS MJ, VAN DIJK CGM, KUIJPERS WC, WORTELBOER HM, VAN HELDEN HPM 2011 Increasing oxime efficacy by blood-brain barrier modulation. Toxicol Lett 206(1): 67-71

https://doi.org/10.1016/j.toxlet.2011.05.231

94. DOCTOR BP, SAXENA A 2005 Bioscavengers for the protection of humans against organophosphate toxicity. Chem Biol Interact 157: 167-171 https://doi.org/10.1016/j.cbi.2005.10.024

95. LENZ DE, MAXWELL DM, KOPLOVITZ I, CLARK CR, CAPACIO BR, CERASOLI DM, FEDERKO JM, LUO C, SAXENA A, DOCTOR BP, OLSON C 2005 Protection against soman or VX poisoning by human butyrylcholinesterase in guinea pigs and cynomolgus monkeys. Chem Biol Interact 157-158: 205-210 https://doi.org/10.1016/j.cbi.2005.10.025
96. SAXENA A, SUN W, DABISCH PA, HULET SW, HASTINGS NB, JAKUBOWSKI EM, MIODUSZEWSKI RJ, DOCTOR BP 2008 Efficacy of human serum butyrylcholinesterase against sarin vapor. Chem Biol Interact 175: 267-272 https://doi.org/10.1016/j.cbi.2008.05.022

97. KOVARIKZ, KATALINIĆ M, ŠINKO G, BINDER J, HOLAS O, JUNG YS, MUSILOVA L, JUN D, KUČA K 2010 Pseudocatalytic scavenging: Searching for a suitable reactivator of phosphorylated butyrylcholinesterase. Chem Biol Interact 187(1-3): 167-171 https://doi.org/10.1016/j.cbi.2010.02.023

98. RADIĆ Z, DALE T, KOVARIK Z, BEREND S, GARCIA E, ZHANG L, AMITAI G, GREEN C, RADIĆ B, DUGGAN BM, AJAMI D, REBEK J, TAYLOR P 2013 Catalytic detoxification of nerve agent and pesticide organophosphates by butyrylcholinesterase assisted with non-pyridinium oximes. Biochem J 450(1): 231-242 https://doi.org/10.1042/BJ20121612

99. KOVARIK Z, MAČEK HRVAT N, KATALINIĆ M, SIT RK, PARADYSE A, ŽUNEC S, MUSILEK K, FOKIN VV, TAYLOR P, RADIĆ Z 2015 Catalytic soman scavenging by the Y337A/F338A acetylcholinesterase mutant assisted with novel site-directed aldoximes. Chem Res Toxicol 28(5): 1036-1044 https://doi.org/10.1021/acs.chemrestox.5b00060

100. MAČEK HRVAT N, ŽUNEC S, TAYLOR P, RADIĆ Z, KOVARIK Z 2016 HI-6 assisted catalytic scavenging of VX by acetylcholinesterase choline binding site mutants. Chem Biol Interact 259: 148-153 https://doi.org/10.1016/j.cbi.2016.04.023

101. KOVARIK Z, MAČEK HRVAT N 2020 Efficient detoxification of nerve agents by oxime-assisted reactivation of acetylcholinesterase mutants. Neuropharmacology. Neuropharmacology 171:108111 https://doi.org/10.1016/j.neuropharm.2020.108111

102. GUO L, REN J, JIANG X 2012 Perspectives on brain-targeting drug delivery systems. Curr Pharm Biotechnol 13(12): 2310-2318 https://doi.org/10.2174/138920112803341770

103. BHISE S, YADAV A, AVACHAT A, MALAYANDI R 2008 Bioavailability of intranasal drug delivery system. Asian J Pharm 2(4): 201 https://doi.org/10.4103/0973-8398.45032

104. ILLUM L 2012 Nasal drug delivery - Recent developments and future prospects. J Control Release 161(2): 254-263 https://doi.org/10.1016/j.jconrel.2012.01.024

105. DI L, KERNS EH 2016 Chapter 19 - Pharmacokinetics, In: Di L, Kerns E H (eds) Drug-Like Properties: Concepts, Structure Design and Methods from ADME to Toxicity Optimization, Academic Press, Cambridge, Massachusetts, USA, p 267-281 https://doi.org/10.1016/B978-0-12-801076-1.00019-8

106. GARRIGUE H, MAURIZISS JC, MADELMONT JC, NICOLAS C, MEYNIEL J M, LOUVEL A, DEMERSEMAN P, SENTENAC-ROUMANOU H, VEYRE A 1991 Disposition and metabolism of acetylcholinesterase reactivators 2PAM-I, TMB4 and R665 in rats submitted to organophosphate poisoning. Xenobiotica 21(5): 583-595 https://doi.org/10.3109/00498259109039498

107. GREEN MD, TALBOT BG, CLARK CR 1986 Pharmacokinetics of pralidoxime chloride in the rat. Life Sci 39(23): 2263-2269 https://doi.org/10.1016/0024-3205(86)90405-4

108. MOORE DH, HAYWARD IJ, TUCKER FS, LUKEY B 1991 HI-6 and 2-PAM in sheep: Pharmacokinetics and effects on muscle tissue following intramuscular injection. Biopharm Drug Dispos 12(3): 223-232 https://doi.org/10.1002/bdd.2510120307

109. SIDELL FR, MARKIS JE, GROFF WA, KAMINSKIS A 1974 Enhancement of drug absorption after administration by an automatic injector. J Pharmacokinet Biopharm 2(3): 197-210 https://doi.org/10.1007/BF01059762

110. SIDELL FR, GROFF WA 1971 Intramuscular and intravenous administration of small doses of 2-pyridinium aldoxime methochloride to man. J Pharm Sci 60 (8): 1224-1228 https://doi.org/10.1002/jps.2600600823 
111. SIDELL FR, MARKIS JE, GROFF W, KAMINSKIS A 1974 Enhancement of drug absorption after administration by an automatic injector. J Pharmacokinet Biopharm 2: 197-210 https://doi.org/10.1007/BF01059762

112. GARRIGUE H, MAURIZIS JC, NICOLAS C, MADELMONT JC, GODENECHE D, HULOT T, MORGE X, DEMERSEMAN P, SENTENAC-ROUMANOU H, VEYRE A 1990 Disposition and metabolism of two acetylcholinesterase reactivators, pyrimidoxime and HIG, in rats submitted to organophosphate poisoning. Xenobiotica 20(7): 699-709 https://doi.org/10.3109/00498259009046886

113. SIMONS KJ, BRIGGS CJ 1985 Disposition of HI-6 oxime in rats after intravenous and intramuscular administration. J Pharm Pharmacol 37(5): 367-369 https://doi.org/10.1111/j.2042-7158.1985.tb05088.x

114. ŽDÁROVÁ KARASOVÁJ, NOVOTNY L, ANTOS K, ZIVNA H, KUCA K 2010 Time-dependent changes in concentration of two clinically used acetylcholinesterase reactivators (HI-6 and obidoxime) in rat plasma determined by HPLC techniques after in vivo administration. Anal Sci 26(1): 63-67 https://doi.org/10.2116/analsci.26.63

115. ZEMEK F, ŽDÁROVÁ KARASOVÁ J, SEPSOVA V, KUCA K 2013 Acetylcholinesterase reactivators (HI-6, obidoxime, trimedoxime, K027, K075, K127, K203, K282): structural evaluation of human serum albumin binding and absorption kinetics. Int J Mol Sci 14(8): 16076-16086 https://doi.org/10.3390/ijms140816076

116. CASSEL G, KARLSSON L, WAARA L, ANG KW, GÖRANSSON-NYBERG A 1997 Pharmacokinetics and effects of HI 6 in blood and brain of soman-intoxicated rats: A microdialysis study. Eur J Pharmacol 332(1): 43-52 https://doi.org/10.1016/S0014-2999(97)01058-3

117. ECOBICHON DJ, COMEAU AM 1989 Kinetics, distribution, and biotransformation of the chemical HI- 6 in the rat, dog, and rhesus monkey. Can J Physiol Pharmacol 68(5): 614-621 https://doi.org/10.1139/y90-089

118. LUNDY PM, HILL I, LECAVALIER P, HAMILTON MG, VAIR C, DAVIDSON C, WEATHERBY KL, BERGER BJ 2005 The pharmacokinetics and pharmacodynamics of two HI-6 salts in swine and efficacy in the treatment of GF and soman poisoning. Toxicology 208(3): 399-409 https://doi.org/10.1016/j.tox.2004.12.001

119. KUŠIC R, BOŠKOVIC B, VOJVODIĆ V, JOVANOVIĆ D 1985 HI-6 in man: Blood levels, urinary excretion, and tolerance after intramuscular administration of the oxime to healthy volunteers. Fundam Appl Toxicol 5: 89-97 https://doi.org/10.1016/0272-0590(85)90118-6

120. SIDELL FR, GROFF WA 1970 Toxogonin: Blood levels and side effects after intramuscular administration in man. J Pharm Sci 59(6): 793-797 https://doi:10.1002/jps.2600590615

121. ŽDÁROVÁ KARASOVÁ J, CHLADEK J, HROCH M, JOSEF F, HNIDKOVA D, KUCA K 2013 Pharmacokinetic study of two acetylcholinesterase reactivators, trimedoxime and newly synthesized oxime K027, in rat plasma. J Appl Toxicol 33(1): 18-23 https://doi.org/10.1002/jat.1699

122. SIDELL FR, GROFF WA, KAMINSKIS A 1972 Toxogonin and pralidoxime: Kinetic comparison after intravenous administration to man. J Pharm Sci 61(11): 1765-1769 https://doi.org/10.1002/jps.2600611115

123. ANDES D, CRAIG WA 2002 Animal model pharmacokinetics and pharmacodynamics: a critical review. Int J Antimicrob Agents 19: 261-268 https://doi.org/10.1016/S0924-8579(02)00022-5

124. THIERMANN H, EYER F, FELGENHAUER N, PFAB R, ZILKER T, EYER P, WOREK F 2010 Pharmacokinetics of obidoxime in patients poisoned with organophosphorus compounds.
Toxicol Lett 197: 236-242

https://doi.org/10.1016/j.toxlet.2010.06.005

125. ŽDÁROVÁ KARASOVÁ J, ZEMEK F, MUSILEK K, KUCA K 2013 Time-dependent changes of oxime K027 concentrations in different parts of rat central nervous system. Neurotox Res 23(1): 63-68 https://doi.org/10.1007/s12640-012-9329-4

126. ŽDÁROVÁ KARASOVÁ J, HNÍDKOVÁ D, POHANKA M, MUSÍLEK K, CHILCOTT RP, KUČA K 2012 Pharmacokinetics of acetylcholinesterase reactivator K203 and consequent evaluation of low molecular weight antioxidants/markers of oxidative stress. J Appl Biomed 10(2): 71-78 https://doi.org/10.2478/v10136-011-0015-2

127. ŽDÁROVÁ KARASOVÁ J, KVETINA J, TACHECI I, RADOCHOVA V, MUSILEK K, KUCA K, BURES J 2017 Pharmacokinetic profile of promising acetylcholinesterase reactivators K027 and K203 in experimental pigs. Toxicol Lett 273: 20-25 https://doi.org/10.1016/j.toxlet.2017.03.017

128. SIDELL FR, GROFF WA, ELLIN RI 1969 Blood levels of oxime and symptoms in humans after single and multiple oral doses of 2-pyridine aldoxime methochloride. J Pharm Sci 58(9): 1093-1098 https://doi.org/10.1002/jps.2600580911

129. SIDELL FR, GROFF WA, KAMINSKIS A 1972 Pralidoxime methanesulfonate: Plasma levels and pharmacokinetics after oral administration to man. J Pharm Sci 61(7): 1136-1140 https://doi.org/10.1002/jps.2600610722

130. SIMON GA, TIROSH MS, EDERY H 1976 Administration of obidoxime tablets to man. Plasma levels and side reactions. Arch Toxicol 36(1): 83-88 https://doi:10.1007/BF00277566

131. SIDELL FR, GROFF WA 1971 Toxogonin: Oral administration to man. J Pharm Sci 60(6): 860-863 https://doi.org/10.1002/jps.2600600611

132. JOVANOVIĆ D, MAKSIMOVIĆ M, JOKSOVIĆ D, KOVACEVIĆ V 1989 Oral Forms of the Oxime HI-6: A Study of Pharmacokinetics and Tolerance After Administration to Healthy Volunteers. Vet Hum Toxicol 32(5): 419-421 https://pubmed.ncbi.nlm.nih.gov/2238436/

133. SIMONS KJ, BRIGGS CJ 1983 The pharmacokinetics of HI-6 in beagle dogs. Biopharm Drug Dispos 4(4): 375-388 https://doi.org/10.1002/bdd.2510040409

134. LIGTENSTEIN DA, KOSSEN SP 1983 Kinetic profile in blood and brain of the cholinesterase reactivating oxime HI- 6 after intravenous administration to the rat. Toxicol Appl Pharmacol 71(2): 177-183 https://doi.org/10.1016/0041-008X(83)90334-4

135. SWARTZ RD, SIDELL FR 1974 Renal tubular secretion of pralidoxime in man. Exp Biol Med 146: 419-424 https://doi.org/10.3181/00379727-146-38118

136. VEINLICHOVA A, JANCOVA P, SILLER M, ANZENBACHER P, KUCA K, JUN D, FUSEK J, ANZENBACHEROVA E 2009 Effect of acetylcholinesterase oxime-type reactivators K-48 and HI- 6 on human liver microsomal cytochromes $\mathrm{P} 450$ in vitro. Chem Biol Interact 180(3): 449-453 https://doi.org/10.1016/j.cbi.2009.03.016

137. BENNION BJ, BE NA, MCNERNEY MW, LAO V, CARLSON EM, VALDEZ C A, MALFATTI MA, ENRIGHT HA, NGUYEN TH, LIGHTSTONE FC, CARPENTER TS 2017 Predicting a drug's membrane permeability: A computational model validated with in vitro permeability assay data. J Phys Chem B 121(20): 5228-5237 https://doi.org/10.1021/acs.jpcb.7b02914

138. ŽDÁROVÁ KARASOVÁ J, POHANKA M, MUSILEK K, ZEMEK F, KUCA K 2010 Passive diffusion of acetylcholinesterase oxime reactivators through the blood-brain barrier: Influence of molecular structure. Toxicol Vitr 24(6): 1838-1844 https://doi.org/10.1016/J.TIV.2010.05.009 
139. GALLAGHER E, MINN I, CHAMBERS JE, SEARSON PC 2016 In vitro characterization of pralidoxime transport and acetylcholinesterase reactivation across MDCK cells and stem cell-derived human brain microvascular endothelial cells (BC1-hBMECs). Fluids Barriers CNS 13(10): 1-8 https://doi.org/10.1186/s12987-016-0035-0

140. DAIL MB, MEEK EC, CHAMBERS HW, CHAMBERS JE 2018 In vitro P-glycoprotein activity does not completely explain in vivo efficacy of novel centrally effective oxime acetylcholinesterase reactivators. Drug Chem Toxicol 42(4): 403-408 https://doi.org/10.1080/01480545.2018.1461902

141. SOUKUP O, KORABECNY J, MALINAK D, NEPOVIMOVA E, PHAM NL, MUSILEK K, HRABINOVA M, HEPNAROVA V, DOLEZAL R, PAVEK P, JOST P, KOBRLOVA T, JANKOCKOVA J, GORECKI L, PSOTKA M, NGUYEN TD, BOX K, OUTHWAITE B, CECKOVA M, SORF A, JUN D, KUCA K 2018 In vitro and in silico evaluation of non-quaternary reactivators of $\mathrm{AChE}$ as antidotes of organophosphorus poisoning - a new hope or a blind alley? Med Chem 14(3): 281-292 https://doi.org/10.2174/1573406414666180112105657

142. FIREMARK H, BARLOW CF, ROTH LJ 1964 The penetration of 2-PAM-C14 into brain and the effect of cholinesterase inhibitors on its transport. J Pharmacol Exp Ther 145(2): 252-265 https://pubmed.ncbi.nlm.nih.gov/14214425/

143. PETROIANU GA, LORKE DE, HASAN MY, ADEM A, SHEEN R, NURULAIN S M, KALASZ H 2007 Paraoxon has only a minimal effect on pralidoxime brain concentration in rats. J Appl Toxicol 27(4): 350-357 https://doi.org/10.1002/jat.1213

144. ŽDÁROVÁ KARASOVÁ J, ZEMEK F, KASSA J, KUČA K 2014 Entry of oxime K027 into the different parts of rat brain: Comparison with obidoxime and oxime HI-6. J Appl Biomed 12(1): 25-29 https://doi.org/10.1016/j.jab.2013.01.001

145. FALB A, ERDMANN WD 1969 [Penetration of 14C-obidoxime through the so-called blood-brain barrier of mice and rats]. Arch Toxikol 24(2): 123-32 https://pubmed.ncbi.nlm.nih.gov/5764879/

146. ŽDÁROVÁ KARASOVÁ J, ZEMEK F, BAJGAR J, VASATOVA M, PROCHAZKA P, NOVOTNY L, KUCA K 2011 Partition of bispyridinium oximes (trimedoxime and K074) administered in therapeutic doses into different parts of the rat brain. J Pharm Biomed Anal 54(5): 1082-1087 https://doi.org/10.1016/j.jpba.2010.11.024

147. LORKE DE, KALASZ H, PETROIANU GA, TEKES K 2008 Entry of oximes into the brain: A review. Curr Med Chem 15(8): 743-753 https://doi.org/10.2174/092986708783955563

148. KALÁSZ H, NURULAIN SM, VERESS G, ANTUS S, DARVAS F, ADEGHATE E, ADEM A, HASHEMI F, TEKES K 2015 Mini review on blood-brain barrier penetration of pyridinium aldoximes. J Appl Toxicol 35(2): 116-123 https://doi.org/10.1002/jat.3048

149. CLEMENT JG 1992 Central activity of acetylcholinesterase oxime reactivators. Toxicol Appl Pharmacol 112(1): 104-109 https://doi.org/10.1016/0041-008X(92)90285-Z

150. LORKE DE, HASAN MY, NURULAIN SM, SHEEN R, KUČA K, PETROIANU G A 2007 Entry of two new asymmetric bispyridinium oximes (K-27 and $\mathrm{K}-48$ ) into the rat brain: comparison with obidoxime. J Appl Toxicol 27(5): 482-490 https://doi.org/10.1002/jat.1229

151. SHIH T-M, SKOVIRA JW, O'DONNELLJC, MCDONOUGH JH 2010 Treatment with tertiary oximes prevents seizures and improves survival following sarin intoxication. J Mol Neurosci 40(1-2): 63-69 https://doi.org/10.1007/s12031-009-9259-7

152. SHIH T-M, GUARISCO JA, MYERS TM, KAN RK, MCDONOUGH JH 2011 The oxime pro-2-PAM provides minimal protection against the CNS effects of the nerve agents sarin, cyclosarin, and VX in guinea pigs. Toxicol Mech Methods 21(1): 53-62 https://doi.org/10.3109/15376516.2010.529190

153. KASSAJ,ŽDÁROVÁ KARASOVÁJ, TESAROVAS, MUSILEK K, KUCA K, JUNG YS 2010 A comparison of neuroprotective efficacy of the oxime K203 and its fluorinated analogue (KR22836) with obidoxime in tabun-poisoned rats. Basic Clin Pharmacol Toxicol 107(5): 861-867 https://doi.org/10.1111/j.1742-7843.2010.00588.x

154. BAJGAR J, JAKL A, HRDINA V 1972 The influence of obidoxime on acetylcholinesterase activity in different parts of the mouse brain following isopropylmethyl phosphonofluoridate intoxication. Eur J Pharmacol 19: 199-202 https://doi.org/10.1016/0014-2999(72)90009-x.

155. VAN HELDEN HPM, BUSKER RW, MELCHERS BPC, BRUIJNZEEL PLB 1996 Pharmacological effects of oximes: how relevant are they? Arch Toxicol 70(12): 779-786 https://doi.org/10.1007/s002040050340

156. CLEMENT JG, BAILEY DG, MADILL HD, TRAN LT, SPENCE JD 1995 The acetylcholinesterase oxime reactivator HI-6 in man: Pharmacokinetics and tolerability in combination with atropine. Biopharm Drug Dispos 16(5): 415-425 https://doi.org/10.1002/bdd.2510160506

157. SPICAKOVA A, ANZENBACHER P, LISKOVA B, KUCA K, FUSEK J, ANZENBACHEROVA E 2016 Evaluation of possible inhibition of human liver drug metabolizing cytochromes P450 by two new acetylcholinesterase oxime-type reactivators. Food Chem Toxicol 88: 100-104 https://doi.org/10.1016/J.FCT.2015.11.024

158. MAXWELL DM, LENZ DE, GROFF WA, FROEHLICH H 1987 The effects of blood flow and detoxification on in vivo cholinesterase inhibition by soman in rats. Toxicol Appl Pharmacol 88: 66-76 https://doi.org/10.1016/0041-008X(87)90270-5

159. ASHANI Y, BHATTACHARJEE AK, LEADER H, SAXENA A, DOCTOR BP 2003 Inhibition of cholinesterases with cationic phosphonyl oximes highlights distinctive properties of the charged pyridine groups of quaternary oxime reactivators. Biochem Pharmacol 66(2): 191-202 https://doi.org/10.1016/s0006-2952(03)00204-1

160. ELHUSSEINY A, COHEN Z, OLIVIER A, STANIMIROVIC DB, HAMEL E 1999 Functional acetylcholine muscarinic receptor subtypes in human brain microcirculation: Identification and cellular localization. J Cereb Blood Flow Metab 19: 794-802 https://doi.org/10.1097/00004647-199907000-00010

161. GRAUER E, NATHAN DB, LUSTIG S, KOBILER D 2001 Viral neuroinvasion as a marker for BBB integrity following exposure to cholinesterase inhibitors. Life Sci 68: 985-990 https://doi.org/10.1016/S0024-3205(00)01000-6

162. SCREMIN OU, SHIH T-M, HUYNH L, ROCH M, SUN W, CHIALVO DR, JENDEN DJ 2005 Low-dose cholinesterase inhibitors do not induce delayed effects on cerebral blood flow and metabolism. Pharmacol Biochem Behav 80(4): 529-540 https://doi.org/10.1016/j.pbb.2004.12.013

163. DUNN MA, SIDELL FR 1989 Progress in medical defense against nerve agents. JAMA 262(5): 649-652 https://doi.org/10.1001/jama.1989.03430050065028 
